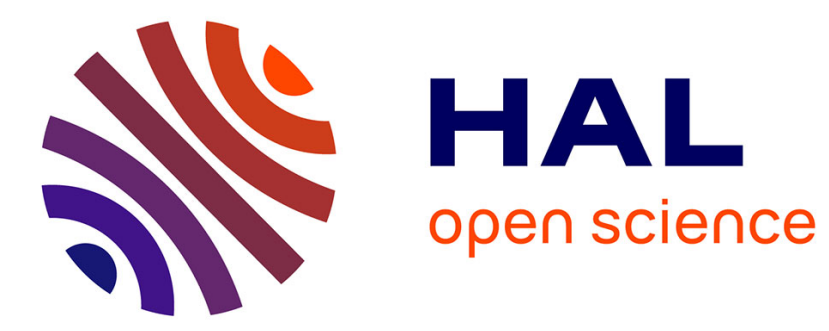

\title{
Age, duration and mineral markers of magma interactions in the deep crust: an example from the Pyrenees
}

Daniel Vielzeuf, Jean-Louis Paquette, J. Clemens, G. Stevens, Abdelmouhcine Gannoun, K. Suchorski, A. Saúl

\section{To cite this version:}

Daniel Vielzeuf, Jean-Louis Paquette, J. Clemens, G. Stevens, Abdelmouhcine Gannoun, et al.. Age, duration and mineral markers of magma interactions in the deep crust: an example from the Pyrenees. Contributions to Mineralogy and Petrology, 2021, 176 (5), 10.1007/s00410-021-01789-2 . hal03228280

\section{HAL Id: hal-03228280 \\ https://hal.uca.fr/hal-03228280}

Submitted on 18 May 2021

HAL is a multi-disciplinary open access archive for the deposit and dissemination of scientific research documents, whether they are published or not. The documents may come from teaching and research institutions in France or abroad, or from public or private research centers.
L'archive ouverte pluridisciplinaire HAL, est destinée au dépôt et à la diffusion de documents scientifiques de niveau recherche, publiés ou non, émanant des établissements d'enseignement et de recherche français ou étrangers, des laboratoires publics ou privés. 


\title{
Age, duration and mineral marking of magma interactions in the deep crust: an example from the Pyrenees
}

D. Vielzeuf ${ }^{1}$ - J-L. Paquette ${ }^{2}$ - J. D. Clemens $^{3} \cdot$ G. Stevens $^{3} \cdot$ A. Gannoun ${ }^{2}$ - K. Suchorski ${ }^{2} \cdot$ A. Saúl ${ }^{1}$

D. Vielzeuf

vielzeuf@cinam.univ-mrs.fr

${ }^{1}$ Aix Marseille Université, CNRS, Centre Interdisciplinaire de NanoScience de Marseille, Marseille, France

${ }^{2}$ Laboratoire Magmas et Volcans, Université Clermont Auvergne, Clermont-Ferrand, France

${ }^{3}$ Department of Earth Sciences, Stellenbosch University, Matieland, South Africa

\begin{abstract}
We report in-situ dating, and $\mathrm{Hf}$ and $\mathrm{O}$ isotope studies of zircon crystals, together with electron microprobe imaging of garnet crystals from a migmatitic diorite containing noritic globules, in the Ursuya massif (French Pyrenees). Diorite zircon crystals have old inherited cores and $295 \pm 2$ Ma rims, while those in the norite are homogeneous, with lower $\mathrm{U}$ and $\mathrm{Pb}$, and higher Th and Th/U ratios than in the diorite zircon rims. The $295 \mathrm{Ma}$ dates represent the crystallisation age of hybridised crustal melts. Norite zircon crystals display similar ages (298 $\pm 3 \mathrm{Ma}$ ) than the diorite zircon rims, interpreted as the crystallisation age of the norite. Hf isotopes indicate that the noritic magmas were already crustally contaminated prior to intrusion at their present locations. The contrasting behaviours of slow- and fast-diffusing species within garnet (e.g. P vs Ca) caused sharp P and diffuse Ca core-rim transitions.
\end{abstract}


Modelling of garnet $\mathrm{Ca}$ diffusion profiles suggests a duration of $2 \pm 1 \mathrm{Myr}$ for the magma interactions in the deep crust. Integrated with granite dating, these data provide insights into pulsations in the regional thermal event that concluded the Hercynian orogenic cycle.

Keywords: lower crust · partial melting · diffusion · mantle/crustal melt · garnet · zircon · calcium $\cdot$ phosphorus $\cdot$ hafnium

\section{Introduction}

There are many signs that mafic, mantle-derived magmas interact with the deep crust. In terms of physical exchanges, mantle heat advected into the deep crust is regarded as a critical driver of high-grade regional metamorphism, especially in cases where the inferred thermal gradients significantly exceed those that can be achieved through radioactive decay and thermal blanketing (e.g. Vielzeuf et al. 1990; Thompson and Connolly 1995; Ganguly et al. 1995). During granulite-facies metamorphism, rocks are not only heated and undergo mineral reactions but, at temperatures $\geq 800^{\circ} \mathrm{C}$, partial melting reactions occur in many common crustal rock types, and these can take place in the absence of any free volatile phase. In one conception of the crustal system, the mantle supplies heat and mafic magma to the deep crust, and the crust responds by partially melting to form granitic magmas that can ascend into the upper crust to form plutons or volcanic complexes. Thus, in this conception, mantle melting, high-grade metamorphism, crustal melting, granitic magma generation and crustal differentiation are seen as inextricably linked (e.g. Clemens 1990; Vielzeuf et al. 1990).

It is clear that what have been called S-type granitic rocks (Chappell and White 1974, 2001) are produced by crustal melting, in the kind of scheme outlined above. These peraluminous rocks have chemical and isotopic characteristics that are inherited from their aluminous, metasedimentary sources (Clemens 2003; Villaros et al. 2012) and experiments 
have confirmed the viability of this hypothesis (e.g. Conrad et al. 1988; Vielzeuf and Holloway 1988; Vielzeuf and Montel 1994; Stevens et al. 1997). However, though the crustal, metasedimentary component dominates, it is possible that there were minor chemical inputs from the mafic heat-source magmas. The phase-equilibrium modelling of Clemens et al. (2011) showed that a magma could retain S-type characteristics despite containing up to $20 \%$ of a mafic to intermediate igneous component. One way in which such a mantle component could be introduced would be for crustal melts to chemically interact with the mafic magma that introduced the heat necessary for crustal melting, although, as noted, the phaseequilibrium constraints appear to place an upper limit of around $20 \%$.

The great majority of granitic plutons, worldwide, contain various kinds of enclaves (i.e. rock inclusions). Among these, there is a class that have come to be known as igneous microgranular enclaves (or sometimes mafic microgranular enclaves, though the majority are not actually mafic). These are present in both I- and S-type host rocks and have commonly been assumed to be products of magma mixing — signs of crust-mantle interaction. However, the textural, mineralogical, chemical and isotopic characteristics of these enclaves suggest that they only mingled with their host magmas at emplacement levels, with variable degrees of hybridization of the enclave magma by the granite (see e.g. Clemens et al. 2017). Such enclaves most likely represent small volumes of high-temperature hybrid magmas that were formed by mixing between mantle-derived and crustal melts, near the depths of the granitic magma sources (Clemens and Bezuidenhout 2014; Clemens et al. 2017).

During crustal melting induced through heat advected by mantle-derived magmas, there is clearly considerable opportunity for both physical and chemical interactions between coexisting mafic and silicic melts. However, what is unclear is the true extent to which such interactions occur and the timescales involved. General impressions can be gained from work on magma mingling and mixing, enclave-host interactions and experiments that show that 
melt connectivity is possible at quite low melt fractions (e.g. Lupulescu and Watson 1999) while magma mixing, to form large volumes of hybrid magma, is thermomechanically unlikely (e.g. McBirney 1980; Sparks and Marshall 1986). Thus, we are left with the question of whether there is much chemical interaction between mafic magmas and silicic crustal melts and, if there is, in what context (where), how much, and how much time is necessary for this to take place.

Due to its ability to incorporate a large number of elements in different structural positions, garnet has long been recognised as an excellent recorder of pressure, temperature or bulk compositional changes in geological processes. If chemical heterogeneities in garnets can be used to reveal the geological history of the rock, the erasure of chemical heterogeneities by chemical diffusion can tell us about the duration of the process. The fact that some elements diffuse more rapidly than others can be helpful in this respect. Below, we combine diffusion kinetic modelling in garnet and zircon geochronology to determine both absolute ages and durations of magma interactions in the deep crust. We address these questions through the study of zoning patterns preserved in garnet and zircon crystals in a mixed rock from the Pyrenees that underwent high-grade metamorphism during Hercynian times.

\section{Geologic setting}

A significant thermal anomaly occurred in the Hercynian belt at ca $310 \mathrm{Ma}$, in response to the lithospheric extension that followed collision (Pin and Vielzeuf 1983). This event was responsible for a profound restructuring of the continental crust here. In the Pyrenees, which form part of the Hercynian belt, a region referred to as the North Pyrenean Zone (Fig. 1) underwent major subsequent tectonic processes during Alpine times (at 100 to $40 \mathrm{Ma}$ ). This included crustal thinning related to transcurrent movements, followed by a succession of compressive stages. This succession of events exhumed the Hercynian crust, from deep to 
upper crustal levels, in several individual massifs. Thus, in this region, it is possible to reconstruct a cross-section of the crust as it existed at the close of the Hercynian orogeny (at $300 \mathrm{Ma}$ ). The Ursuya massif is located in the western part of the North Pyrenean Zone (Fig. 1), and includes micaceous schists and aluminous paragneisses that contain quartz, plagioclase, K-feldspar, biotite, sillimanite, garnet and cordierite.
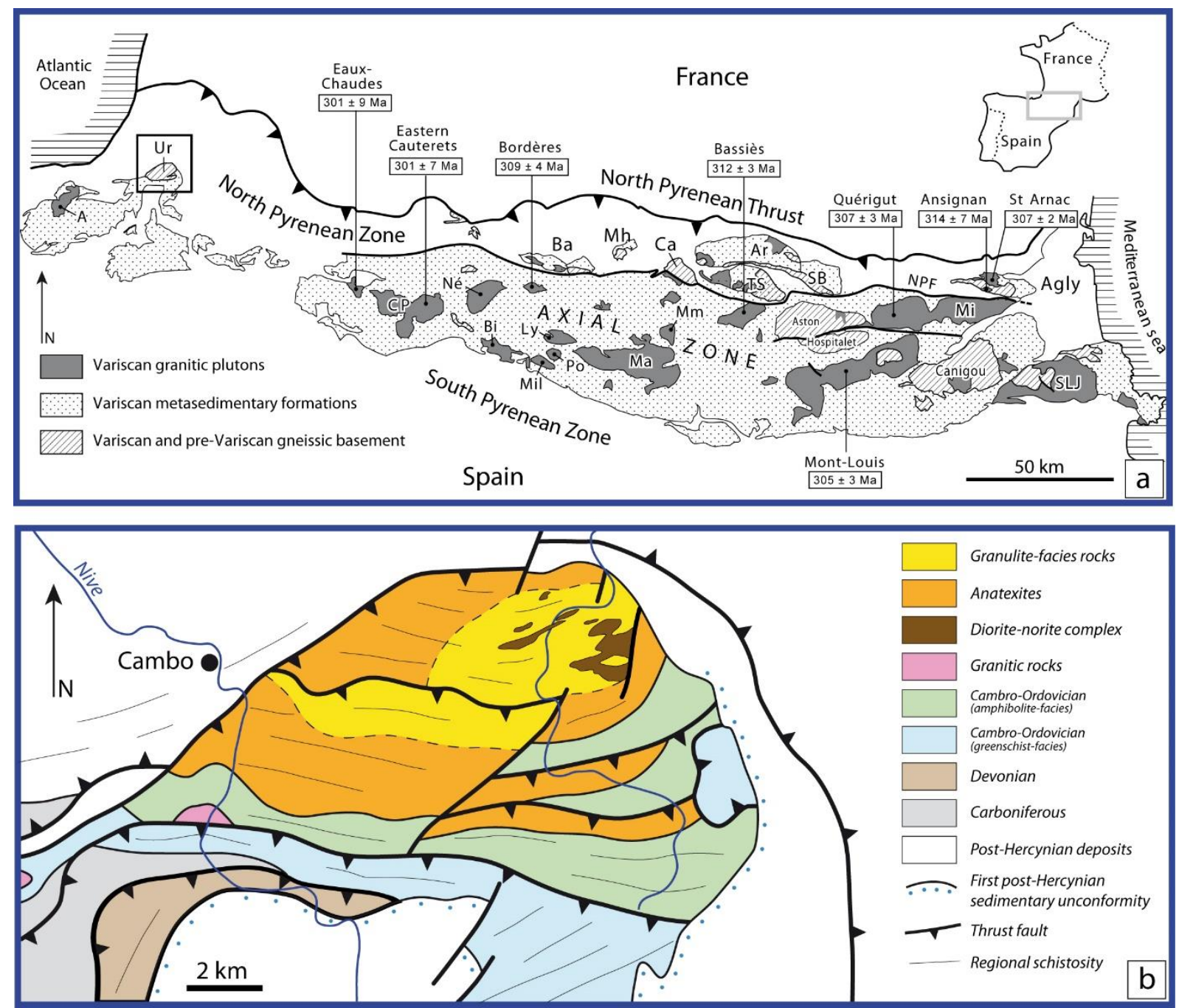

Fig. 1. The Ursuya Massif in the Variscan Pyrenees. (a) Structural sketch of the Pyrenees showing, from west to east,(1) the North Pyrenean massifs [Ursuya (Ur), Barousse (Ba), Milhas (Mh), Castillon (Ca), Arize (Ar), Trois-Seigneurs (TS), Saint-Barthélémy (SB) and Agly]; (2) the main granitic plutons of the Axial Zone [Aya (A), Eaux-Chaudes, Cauterets-Panticosa (CP), Néouvielle (Né), Bielsa (Bi), Bordères, Millares (Mil), Posets (Po), Lys-Caillaouas (Ly), Maladeta (Ma), Marimanha (Mm), Bassiès, Mont-Louis, Quérigut, Millas (Mi) and Saint Laurent-La Jonquera (SLJ)]. NPF, North Pyrenean Fault. Modified after Olivier et al. (2008). (b) Geological map of the Ursuya massif modified after Barnolas and Chiron (1995). Contours of the migmatitic diorites after Boissonnas (1974). 
In the north-eastern part of the massif, there are outcrops of silicic and mafic granulites, together with dioritic migmatites - the quartz-biotite-garnet diorite of Boissonnas (1974). These migmatites are unaltered and heterogeneous, and contain biotite-garnet-rich zones mixed (on the decimetre scale) with (1) quartzofeldspathic domains that are devoid of biotite but extremely rich in garnet, and (2) coarse-grained mafic globules composed of orthopyroxene and plagioclase (i.e. norites). A representative rock slice is displayed in Fig. 2.

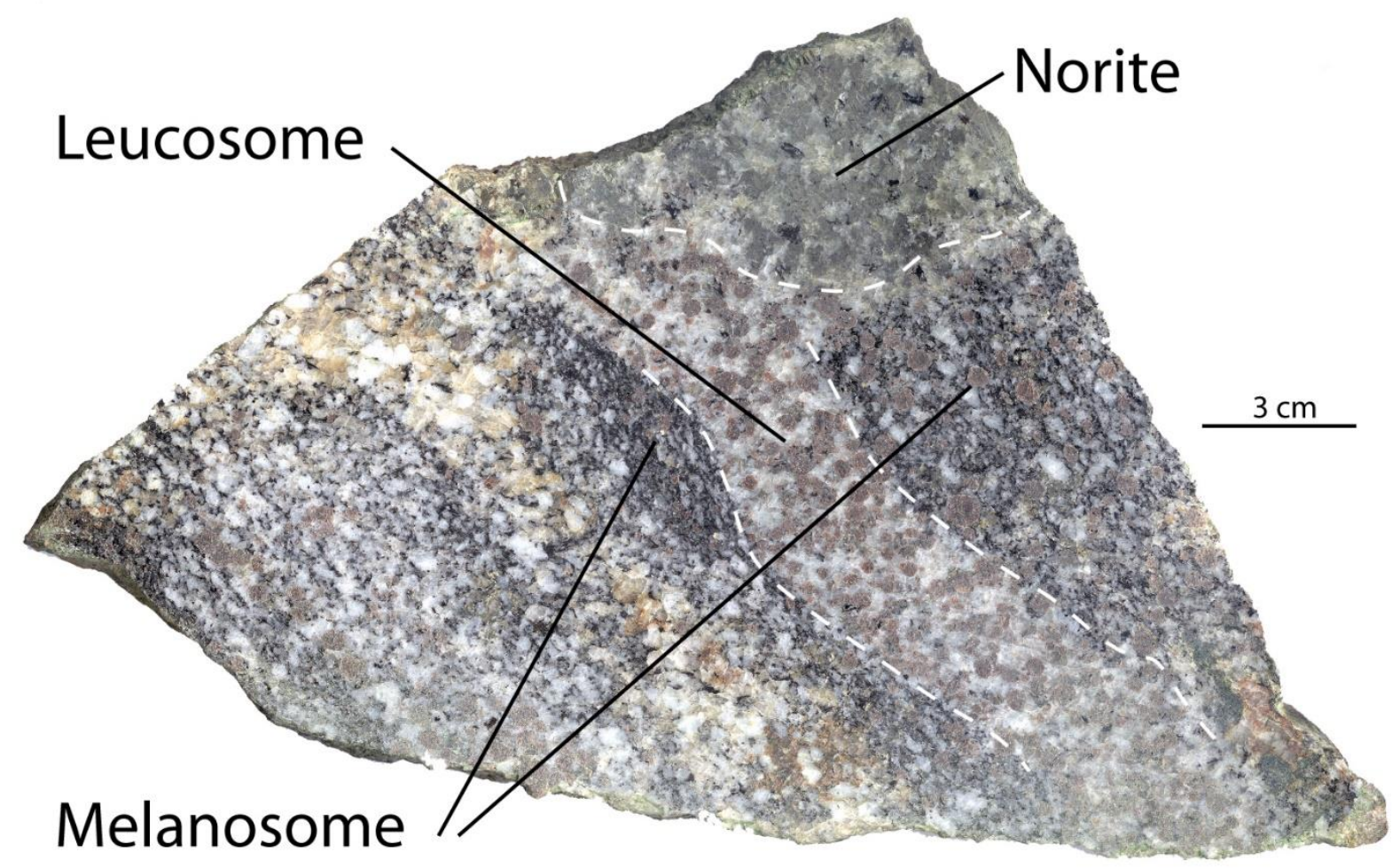

Fig. 2. Polished slice of the rock of interest (sample\# U822). All studied garnet crystals and zircon crystals come from a similar rock slice. Zircon crystals were extracted from the leucosome, melanosome and noritic parts, separately

Using the Grt-Pl-Sill-Qtz and Grt-Pl-Opx-Qtz geothermometers, Vielzeuf (1984) estimated the conditions of crystallization of the deepest and highest-temperature granulites in the Ursuya massif. They found temperatures and pressures in the range 0.55-0.6 GPa, 700-850 ${ }^{\circ} \mathrm{C}$. Later, following an experimental study on partial melting of metagreywackes by Vielzeuf 
and Montel (1994), Vielzeuf et al. (2005) estimated that the coexistence of biotite, garnet, plagioclase, quartz and orthopyroxene (and inferred melt), in some dioritic migmatites, constrains temperatures and pressures to the range of $860 \pm 20{ }^{\circ} \mathrm{C}$ and $0.6 \mathrm{GPa}$. New thermodynamic modelling allowed construction of pseudosections for the diorite bulk composition given in Vielzeuf (1984), with the $\mathrm{H}_{2} \mathrm{O}$ content adjusted to be consistent with a fully hydrated rock undergoing fluid-absent partial melting at mid-crustal pressures. In agreement with previous estimates, this study located the stability field of the $\mathrm{Bt}+\mathrm{Gt}+$ melt+Ilm+Pl+Qtz assemblage at $P>0.6 \mathrm{GPa}$, within a narrow $T$ range of $860 \pm$ $10{ }^{\circ} \mathrm{C}$. Calculations were performed using Rcrust version 2017-10-26 (Mayne et al. 2016), using a compiled form of the meemum function (version 6.7.9) from the Perple_X suite of programs (Connolly 2009) in the NCKFMASHTOMn chemical system, using the 2011 revised hp11ver.dat thermodynamic data file from the internally consistent dataset of Holland and Powell (2011). The following phase activity-composition models were used: Fsp(C1) for plagioclase and alkali feldspar (Holland and Powell 2003); Sp(WPC) for spinel (White et al. 2002); Ilm(WPH) for ilmenite (White et al. 2000); and the White et al. (2014) set of models for biotite, cordierite, garnet, melt, orthopyroxene and white mica. To summarize, estimated pressures and temperatures for the crystallization of these rocks are $860 \pm 20{ }^{\circ} \mathrm{C}$ and $0.6 \pm$ $0.05 \mathrm{GPa}$.

As noted by Vielzeuf et al. (2005), the dioritic migmatites are associated with intrusive mafic rocks (norites), at decametre to decimetre scales. This geological situation, in which crustal and mantle magmas spatially and temporally coexisted is an ideal environment to (1) study chemical exchanges between the two systems, (2) determine whether and how such interactions are registered in minerals, and (3) evaluate the duration of such magma interactions in the middle to lower crust. The zircon and garnet crystals studied in the present work came from a large (ca $50 \mathrm{~kg}$ ), fresh sample taken from these migmatites (Fig. 2). 


\section{Materials and Methods}

\section{EMP mapping}

A systematic study of the garnet crystals of the Ursuya dioritic migmatites has been undertaken by X-ray imaging of major and trace elements using an SX100 Cameca electron microprobe (Université Clermont Auvergne, Clermont-Ferrand). The definition of the X-ray images is $512 \times 512$ pixels. For elements like $\mathrm{P}$ and $\mathrm{Ti}$ with low concentrations $(<1000 \mathrm{ppm})$, a high beam current $(1 \mu \mathrm{A})$ and a long counting time (100 ms per pixel) were used. Four images were acquired at the same time during sessions that lasted 8 hours. Major-element concentrations (spot analyses and traverses) were determined using the same instrument with a $15 \mathrm{kV}$ accelerating voltage and a $15 \mathrm{nA}$ sample current. The counting times were 10 seconds on peak and 5 seconds on background. Both natural and synthetic minerals were used as standards. For trace elements such as $\mathrm{Ti}$ and $\mathrm{P}$, the following conditions were used: accelerating voltage $-15 \mathrm{kV}$, sample current $-150 \mathrm{nA}$, counting times $-100 \mathrm{~s}$ on peak and $50 \mathrm{~s}$ on background. For $\mathrm{P}$, a synthetic glass with a garnet composition and $1000 \mathrm{ppm} \mathrm{P}_{2} \mathrm{O}_{5}$ was used as a standard. Note the unusual high beam current and long counting times for Ti and $\mathrm{P}$ maps and analyses.

\section{SIMS analysis of zircon crystals}

Zircon oxygen-isotope ratios $\left({ }^{18} \mathrm{O} /{ }^{16} \mathrm{O}\right)$ were determined with the Cameca IMS 1270 ion microprobe of the French national facility located at CRPG-CNRS Nancy (France) using a $\mathrm{Cs}^{+}$primary beam and electron gun to compensate the charge. Instrumental conditions are described by Rollion-Bard et al. (2003). The ${ }^{16} \mathrm{O}$ and ${ }^{18} \mathrm{O}$ secondary ions were analysed in multicollection mode at a mass resolution of $\sim 3500$. Zircon crystals extracted from the leucosome, melanosome, and norite parts of the large rock sample were mounted in epoxy in 
three different rows with bits of zircon standard at each row end. This setup allowed easy back and forth analyses of zircon standard and zircon crystals with unknown $\delta^{18} \mathrm{O}$ values with minimal change of instrumental conditions. The instrumental mass fractionation was calibrated using the Nancy zircon reference material 91500 with a $\delta^{18} \mathrm{O}$ value of 10.2 per mil. On the SIMS, the ${ }^{18} \mathrm{O} /{ }^{16} \mathrm{O}$ ratios were determined by multiple measurements of the reference material with a precision of $\sim \pm 0.3(1 \sigma)$ and are reported here with $\delta^{18} \mathrm{O}$ notation, in per mil variations relative to the mean ocean water international standard (SMOW), whose ${ }^{18} \mathrm{O} /{ }^{16} \mathrm{O}$ ratio is $2.0052 \times 10^{3}$. The craters produced on the zircon crystals are $\sim 20 \mu \mathrm{m}$ long, $15 \mu \mathrm{m}$ wide, and less than $1 \mu \mathrm{m}$ in depth.

\section{In situ U-Pb zircon dating}

Zircon crystals were separated at the Laboratoire Magmas et Volcans (LMV), ClermontFerrand (France) using standard techniques of crushing and sieving, followed by Wilfley table, magnetic separation and heavy liquids before handpicking under binocular microscope. They were mounted in epoxy, ground and polished to expose crystal interiors.

Cathodoluminescence (CL) imaging was conducted at LMV using a JEOL JSM-5910LV $\mathrm{SEM}$. U-Th-Pb isotope data were measured by laser ablation inductively coupled mass spectrometry (LA-ICP-MS) at LMV. Zircon crystals were ablated under pure He, using a Resonetics Resolution M-50 system equipped with a 193 nm Excimer laser coupled to a Thermo Element XR sector field ICP-MS. $\mathrm{N}_{2}$ was supplemented to Ar and He carrier gas for sensitivity enhancement (Paquette et al. 2014). The laser operated with a spot diameter of 27 $\mu \mathrm{m}$, a repetition rate of $3 \mathrm{~Hz}$, and a fluence of $2.5 \mathrm{~J} / \mathrm{cm}^{2}$. Complete instrumental operating conditions and data-acquisition parameters are described in Table S1.

The Element was tuned to maximize the ${ }^{238} \mathrm{U}$ intensity and minimize $\mathrm{ThO}^{+} / \mathrm{Th}^{+}(<1 \%)$ using the NIST SRM 612 glass. Background levels were measured on-peak with the laser off 
for $\sim 30 \mathrm{~s}$, followed by $\sim 60 \mathrm{~s}$ of measurement with the laser firing and then $\sim 10 \mathrm{~s}$ of washout time (Hurai et al. 2010). Reduction of raw data was carried out using the GLITTER ${ }^{\circ}$ software package (van Achterbergh et al. 2001). Isotope ratios were corrected for laserinduced and instrumental mass fractionation via sample-standard bracketing using the GJ-1 zircon reference material (Jackson et al., 2004). The ${ }^{235} \mathrm{U}$ signal is calculated from ${ }^{238} \mathrm{U}$ based on the ratio ${ }^{238} \mathrm{U} /{ }^{235} \mathrm{U}=137.818$ (Hiess et al. 2012). The 91500 zircon reference material (Wiedenbeck et al. 1995) was analysed along with the samples to independently monitor the external precision and accuracy of the measurements. Owing to the large isobaric interference of ${ }^{204} \mathrm{Hg}$, no common $\mathrm{Pb}$ corrections were applied. Concentrations of $\mathrm{U}$, Th, and $\mathrm{Pb}$ were calculated by normalization to the certified composition of GJ-1 reference material. ${ }^{207} \mathrm{~Pb} /{ }^{206} \mathrm{~Pb}$ versus ${ }^{238} \mathrm{U} /{ }^{206} \mathrm{~Pb}$ diagrams (Tera and Wasserburg 1972) were generated using Isoplot/Ex v. 2.49 software package by Ludwig (2001). Error ellipses for each point are quoted at the $2 \sigma$ level. Systematic errors on both internal and external (quality control) reference materials were propagated into the calculated age by quadratic addition, following the method of Horstwood et al. (2016). Concordia ages calculations were preferred because they take into account the uncertainty on the U decay, they allow discarding analyses with common $\mathrm{Pb}$, and thus represent the most accurate ages.

\section{In-situ Hf isotopes}

Hafnium isotope measurements were performed with a Thermo Scientific Neptune Plus multi-collector ICP-MS coupled to the Resonetics M50E 193 nm laser excimer system (LMV). The MC-ICP-MS is equipped with 9 Faraday cups and amplifiers with $10^{11} \Omega$. Data were collected in static mode $\left({ }^{171} \mathrm{Yb},{ }^{173} \mathrm{Yb},{ }^{174} \mathrm{Hf},{ }^{175} \mathrm{Lu},{ }^{176} \mathrm{Hf}-{ }^{176} \mathrm{Yb}-{ }^{176} \mathrm{Lu},{ }^{177} \mathrm{Hf},{ }^{178} \mathrm{Hf}\right.$,

${ }^{179} \mathrm{Hf}$ ). The overall operating conditions and instrument settings are reported in Table S1 and described in Moyen et al. (2017) and Paquette et al. (2017). Each LA-MC-ICPMS analysis 
consisted of $20 \mathrm{~s}$ of gas background data followed by $40 \mathrm{~s}$ of ablation. With an integration time of $1 \mathrm{~s}$, each analysis typically produced 36-40 isotopic ratios. Mass bias effects on $\mathrm{Hf}$ were corrected using an exponential law and a true value for ${ }^{179} \mathrm{Hf} /{ }^{177} \mathrm{Hf}$ of 0.7325 (Patchett and Tatsumoto 1980; Patchett et al. 1981). Data were reduced in the following order, and based upon user-selected background and sample integration intervals. Firstly, the mean signal intensity of the background was subtracted from the signal acquired during the laser firing onto the sample. $\beta \mathrm{Yb}$ was determined using the ${ }^{173} \mathrm{Yb} /{ }^{171} \mathrm{Yb}$ measured during each analysis and the reference value for ${ }^{173} \mathrm{Yb} /{ }^{171} \mathrm{Yb}$ of 1.132685 (Chu et al. 2002; Fisher et al. 2011a). The ${ }^{176} \mathrm{Yb}$ and ${ }^{176} \mathrm{Lu}$ isobaric interference on ${ }^{176} \mathrm{Hf}$ were determined using ${ }^{176} \mathrm{Yb} /{ }^{173} \mathrm{Yb}$ of 0.79618 and the measured interference-free ${ }^{175} \mathrm{Lu}$ mass assuming that $\beta_{\mathrm{Lu}}=\beta \mathrm{Yb}$, and using the reference value for ${ }^{176} \mathrm{Lu} /{ }^{175} \mathrm{Lu}$ of 0.02655 (Vervoort et al. 2004). Both determined ${ }^{176} \mathrm{Lu}$ and ${ }^{176} \mathrm{Yb}$ signals were subtracted from the total 176 signal intensity. The mass bias is calculated using the true ${ }^{179} \mathrm{Hf} /{ }^{177} \mathrm{Hf}$ ratio of 0.7325 (Patchett and Tatsumoto, 1980). Finally the interference corrected ${ }^{176} \mathrm{Hf} /{ }^{177} \mathrm{Hf}$ is evaluated according to the following equation:

$$
\left(\frac{176 H f}{177 H f}\right)_{\text {corrected }}=\left(\frac{{ }^{176}(H f+Y b+L u)_{\text {meas }}-{ }^{176} Y b_{\text {cale }}-{ }^{176} L u_{\text {calc }}}{{ }^{177} H f_{\text {meas }}}\right) \times\left(\frac{M 176}{M 177}\right)^{\beta(H f)}
$$

The ${ }^{176} \mathrm{Lu} /{ }^{177} \mathrm{Hf}$ for all samples were corrected for mass bias using $\beta$ Hf. Outlier rejection of the Hf isotopic ratio for each analysis were performed using a two-standard deviation criterion.

The $\varepsilon_{\mathrm{Hf}}(\mathrm{t})$ value is defined as the deviation of the ${ }^{176} \mathrm{Hf} /{ }^{177} \mathrm{Hf}$ of a sample from the CHUR in parts per $10^{4}$. It is calculated according to the $\lambda^{176} \mathrm{Lu}$ value $=1.865 \times 10^{-11} \mathrm{yr}^{-1}$ of Scherer et al. (2001) and the CHUR parameters $\left({ }^{176} \mathrm{Hf} /{ }^{177} \mathrm{Hf}=0.282793 ;{ }^{176} \mathrm{Lu} /{ }^{177} \mathrm{Hf}=0.0338\right)$ of Iizuka et al. (2015).

To certify the Hf isotope results, we checked our analytical reproducibility and correction procedure with systematic measurement of 20 replicates of four synthetic zircon crystals displaying increasing $(\mathrm{Y}+\mathrm{Lu})$ content (Supplementary Table S1). Mean and two standard 
deviation values obtained on MUNZirc 0-2a $\left({ }^{176} \mathrm{Hf} /{ }^{177} \mathrm{Hf}=0.28213 \pm 3\right)$, MUNZirc $1-2 \mathrm{~b}$ $(0.28214 \pm 2)$, MUNZirc 3-2b (0.28215 \pm 2$)$ and MUNZirc 4-2b $(0.28216 \pm 3)$ are fully consistent with reference values (Fischer et al., 2011b).

\section{Results and interpretations}

\section{The garnet narrative}

\section{Previous work}

Garnet crystals recovered from the dioritic migmatites were the subject of a previous study that focused on $\mathrm{O}$ isotope heterogeneities and $\mathrm{O}$ diffusion profiles (Vielzeuf et al. 2005). Below we present a summary of these findings, together with some new information, illustrated with EMP maps. Garnet crystals range from 2 to $7 \mathrm{~mm}$ in diameter, and zoning is visible to the naked eye (Fig. 2). In some garnet crystals $\mathrm{Ca}, \mathrm{Fe}, \mathrm{Mg}, \mathrm{Mn}, \mathrm{Na}, \mathrm{Al}, \mathrm{Ti}, \mathrm{P}, \mathrm{Cr}$, Sc, $\mathrm{Y}$, and $\mathrm{Zr}$ were $\mathrm{X}$-ray mapped with an electron microprobe. The first results indicated that $\mathrm{Zr}, \mathrm{Y}, \mathrm{Sc}, \mathrm{Cr}, \mathrm{Na}, \mathrm{Mn}$ showed no significant or systematic zoning, so emphasis then fell on the other elements in the list. Calcium variations are responsible for the zoning that can be observed in polished rock slices (Fig.2) and we can identify two zones - a Ca-poor inner zone I, and a Ca-rich outer zone II. Phosphorus mapping and the abundance of mineral inclusions allow a further subdivision into zones Ia, Ib, IIa, IIb (Fig. 5). Growth stages of these crystals are thus given a similar notation (i.e. growth stage Ia for zone Ia, etc.).

\section{Zone Ia}

Most garnet cores have relatively low Ca concentrations, with Grs contents in the range of 7 to $10 \mathrm{~mol} \%$, and these cores are also relatively enriched in $\mathrm{P}$ (ca $1000 \mathrm{ppm} \mathrm{P}_{2} \mathrm{O}_{5}$ ). Highly aluminous phases (sillimanite needles and spinel) are common as inclusions in zone Ia. Examples of such garnet cores are shown in Figs 3 to 6. Intriguingly, P, and in some cases, Ti 
display sharp boundaries between zones I and II, mimicking the shapes of garnet crystals that existed prior to the zone II overgrowths. These initial garnet cores can be either rounded in shape (Fig. 3b) or euhedral (Figs 4 and 5) and, in some cases, there are resorption features (e.g. the embayments in Fig. 3d). It seems clear that $\mathrm{P}$ concentrations record a succession of growth and resorption stages. The example in Fig. 4 is spectacular, with internal euhedral shapes and marked oscillatory zoning.

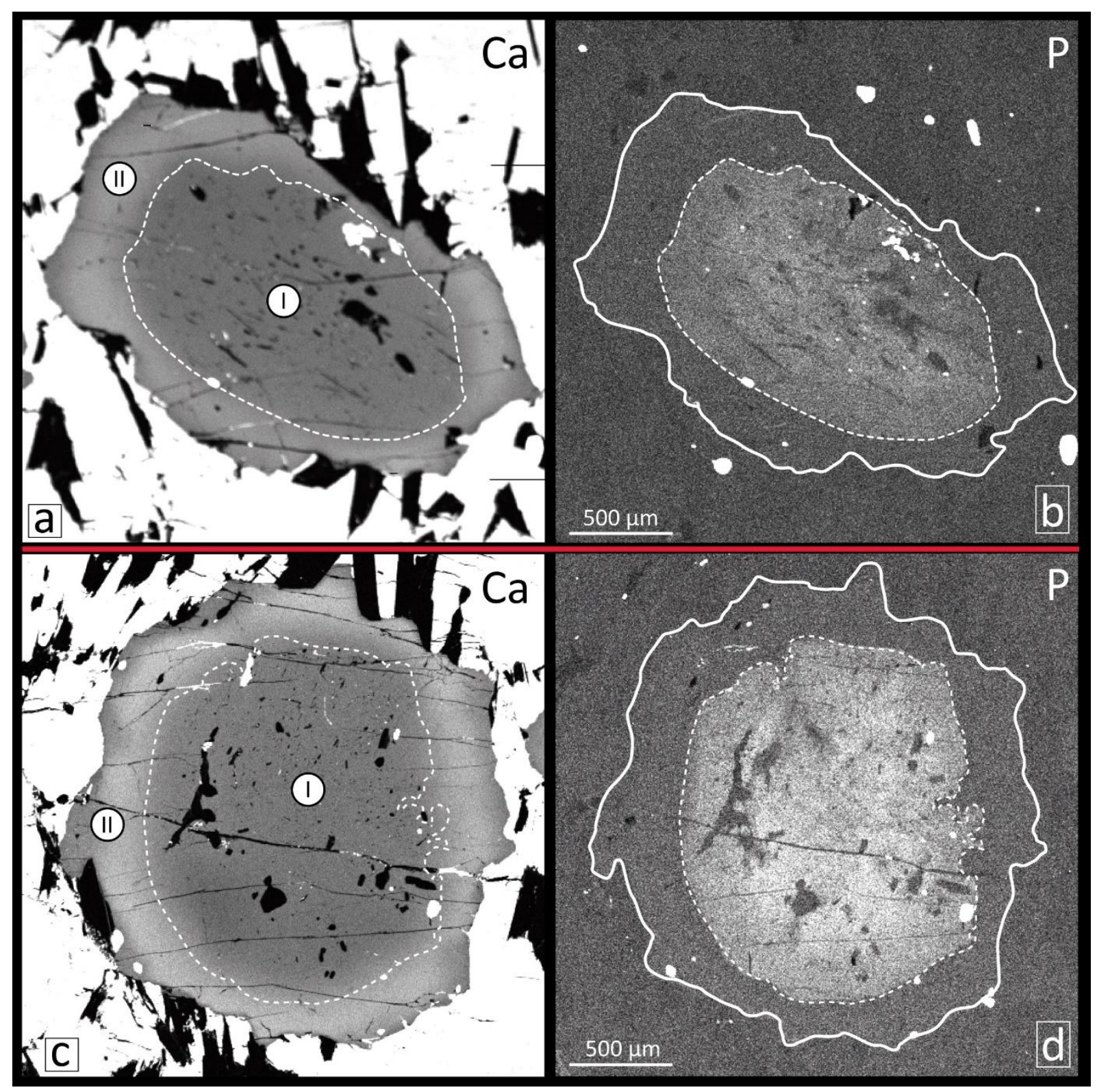

Fig. 3. Calcium and phosphorus EMP maps of two garnet crystals (Grt1 and Grt2) with aluminous inclusions in the core. The garnet external contours are shown as a white line in the P images. The dashed lines in the Ca images indicate the boundary between $P$-rich and P-poor zones 


\section{Zone Ib}

Some large garnet crystals display complex $\mathrm{P}$ zoning patterns. For example, the crystals in Fig. 5 contain a zone (Ib) in which P concentrations are lower than in Ia. Figures $5 \mathrm{c}$ and $\mathrm{d}$ are two different $\mathrm{P}$ images of a particular domain in these garnet crystals (mostly zone $\mathrm{Ib}$ ) taken at a higher spatial resolution. Here, fine details become evident, with patches that have differing concentrations and faint oscillatory zoning. Note that the interfaces between zones Ia and $\mathrm{Ib}$ are discontinuous and anhedral, which suggests a prominent stage of garnet resorption between growth stages Ia and Ib. While P concentrations preserve sensitive records of the growth/resorption histories of these garnet crystals, $\mathrm{Ca}, \mathrm{Fe}$ and $\mathrm{Mg}$ are far less sensitive to these variations. Thus, the mapping of $\mathrm{P}$ heterogeneities provides a means of examining the growth histories of garnet crystals at much higher sensitivity and spatial resolution than is possible with the usual elements (e.g. Fe, $\mathrm{Mn}, \mathrm{Ca}$ and $\mathrm{Mg}$ ).

\section{Zone IIa}

This zone is characterized by higher Ca contents than the previous two (Figs 3 to 6), with Grs between 13 and $15 \mathrm{~mol} \%$ and, in some cases, numerous apatite and/or plagioclase inclusions (Figs. $5 \mathrm{~b}$ and c). In some crystals in which zone $\mathrm{I}$ is absent (either a real absence or through a sectioning effect) there is oscillatory zoning in P concentration, e.g. in Fig. 6 and in Fig. $1 \mathrm{f}$ of Vielzeuf et al. (2005). Figure 6 shows remarkable P and Ti zoning, with a positive correlation between these two elements. Both euhedral shapes and resorption features are observed, and indicate a complex history of successive phases of resorption and crystallization during growth stage II. Image processing, with major thresholding of an Al map, shows the presence of $\mathrm{Al}$ zoning, with a negative correlation between $\mathrm{Al}$ on one hand and $\mathrm{P}$ and $\mathrm{Ti}$ on the other. Substitution mechanisms will be discussed later. 


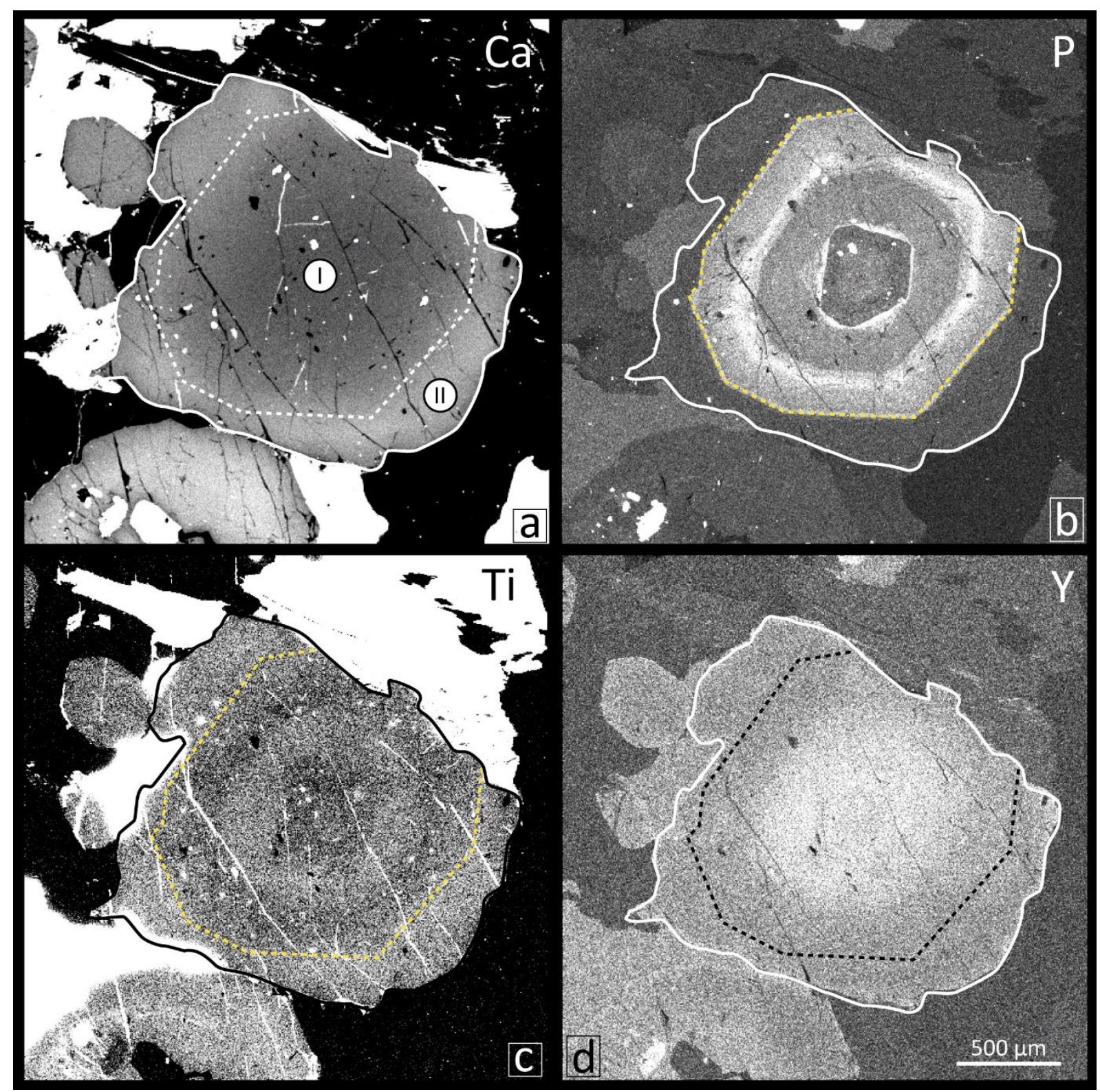

Fig. 4. - Calcium, phosphorus, titanium and yttrium EMP maps of garnet Grt4. The garnet contour is taken from the Ca image. The boundary between P-rich and P-poor zones is plotted on the other chemical maps as a dashed line. Figures $4 a$ and $b$ modified after Vielzeuf et al. (2005)

\section{Zone IIb}

As in zone IIa, the outer parts of garnet crystals have Grs contents > $10 \mathrm{~mol} \%$. However, they display lower and constant $\mathrm{P}$ contents $\left(<200 \mathrm{ppm} \mathrm{P}_{2} \mathrm{O}_{5}\right)$. This zone is devoid of apatite and plagioclase inclusions, and is present in all garnet crystals that we studied (Figs 3 to 6), even though zone IIa is absent in some crystals (e.g. Fig. 3 and 4). 


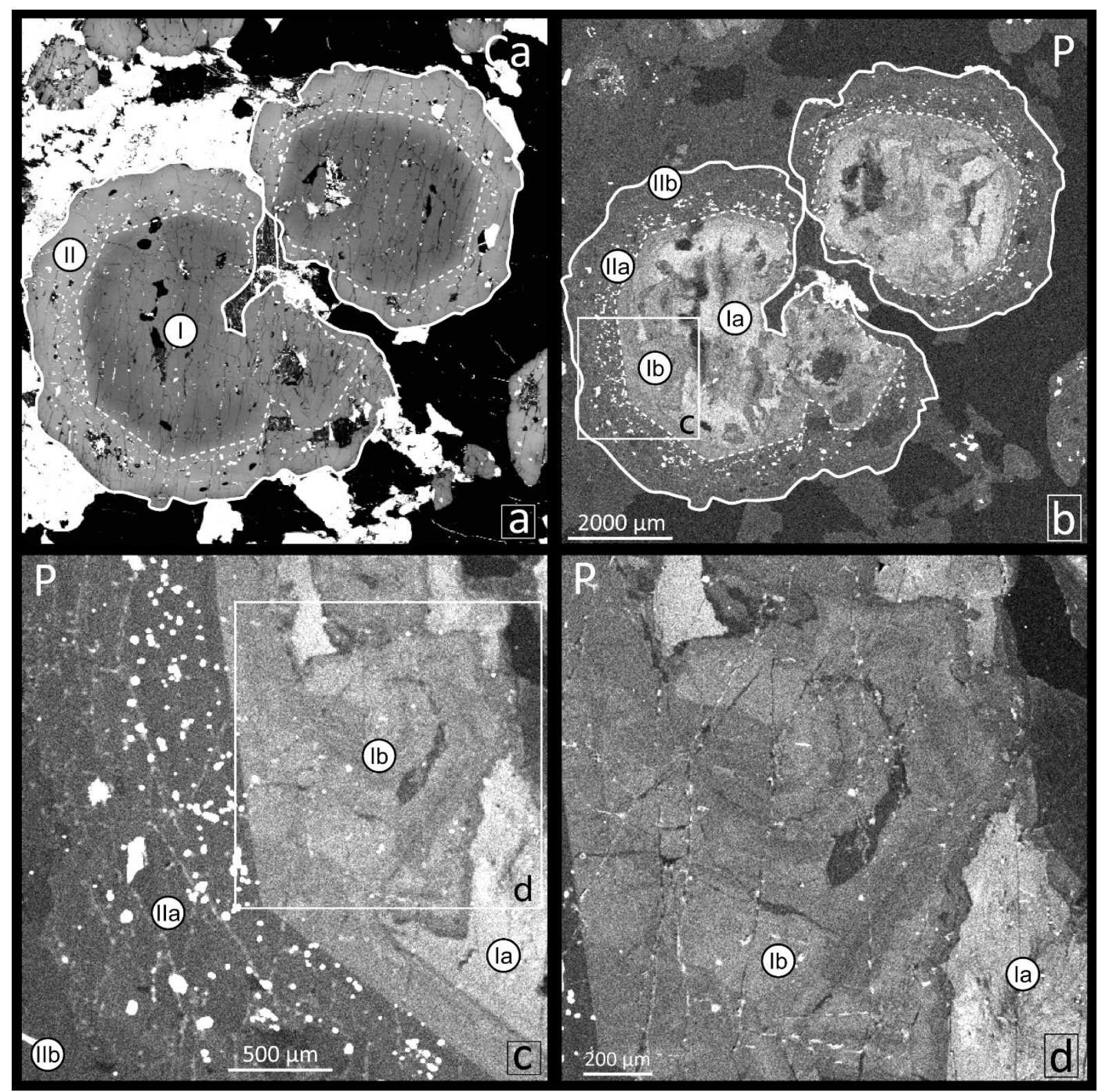

Fig. 5. Calcium and phosphorus EMP maps of garnet crystals Grt14a and Grt14b. The garnet contour in Fig. $5 b$ is taken from the Ca image. The dashed line in the Ca image indicates the boundary between P-rich and Ppoor zones observed in the phosphorus image. $\boldsymbol{c}$ and $\boldsymbol{d}$ : phosphorus maps at a higher resolution of the framed zones shown in $\boldsymbol{b}$ and $\boldsymbol{c}$, respectively. Figures $5 a$ and $b$ were modified after Vielzeuf et al. (2005)

\section{Oxygen isotopes}

In these garnet crystals, $\delta^{18} \mathrm{O}$ values range from 7.3 to $14.4 \%$, with as much as $4.6 \%$ variation in a given crystal. Thus, the zonal variations determined with major and trace elements are also recorded in O-isotope compositions. There is a significant decrease of $\delta^{18} \mathrm{O}$ from core to rim (Figs. 1e and $2 \mathrm{f}$ of Vielzeuf et al. 2005). In zone Ia, $\delta^{18} \mathrm{O}$ ranges from 14.4 to 
$13.5 \%$, in zone Ib from 13.5 to $11.6 \%$, and in zones IIa and IIb from 11.6 down to $7.3 \%$.

The highest $\delta^{18} \mathrm{O}$ values were measured in the garnet crystal with the largest inner core, and the lowest in the crystal with a well-developed outer rim (zone II).

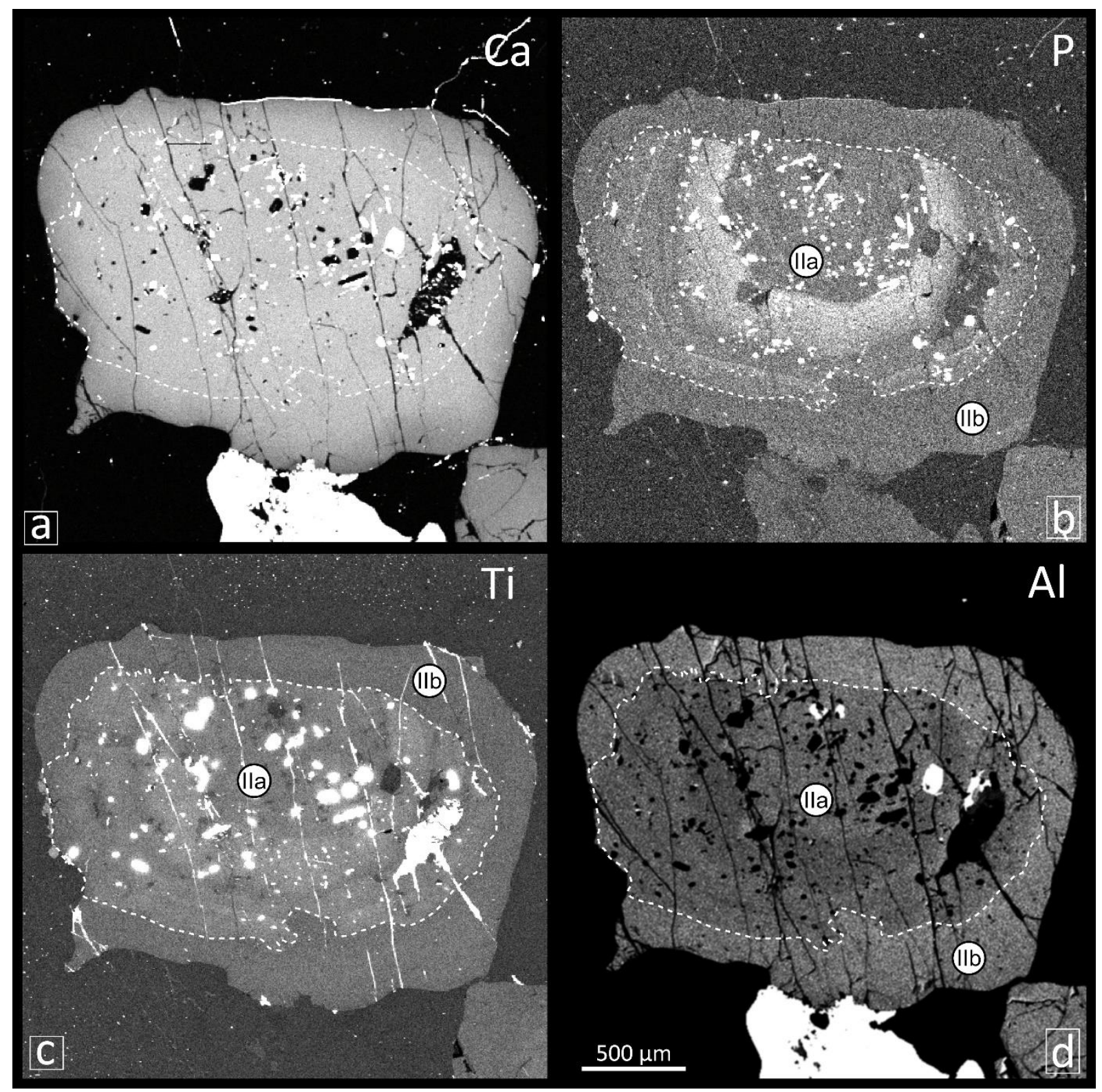

Fig. 6. Calcium, phosphorus, titanium and aluminium EMP maps of garnet Grt3. The dashed line inside the garnet marks the boundary between Ti-rich and Ti-poor zones

\section{A model for garnet growth}

According to Vielzeuf et al. (2005), field relationships (the presence of norite globules in supracrustal rocks), petrology (migmatitic character and decimetric heterogeneities), and mineralogy (major- and trace-element intracrystalline heterogeneities, O-isotope contrasts, 
and the nature and locations of mineral inclusions) all favour the following scenario for the growth of the garnet crystals. In stage Ia, the low Ca contents, the occasional presence of sillimanite and spinel inclusions, and relatively high $\delta^{18} \mathrm{O}$ values (13 to $14 \%$ ) suggest that the earliest garnet crystals had a metamorphic origin and reflect equilibration in a metasedimentary bulk composition. Numerous experimental results (e.g. Green 1976; Conrad et al. 1988; Vielzeuf and Holloway 1988; Patiño Douce and Johnston 1991; Stevens et al. 1997) and petrographic studies (e.g. Clarke and Rottura 1994; Spear and Kohn 1996) indicate that, at appropriate pressures in most crustal compositions, garnet grows during partial melting. During partial melting at constant $P$ and increasing $T$ (stage $\mathrm{Ib}$ ) the Grs content in garnet is expected to decrease slightly (Vielzeuf and Schmidt 2001) together with P, which behaves as an incompatible element. In addition, $\delta^{18} \mathrm{O}$ values in newly formed garnet crystals should not depart significantly from the starting values of the crustal protoliths because fractionation of $\mathrm{O}$ isotopes between minerals and melts is insignificant at magmatic temperatures (Taylor and Sheppard 1986). Thus, in the rocks under consideration, an increase in $T$, presumably in response to proximity to an intrusion of mafic, mantle-derived magma, caused partial melting of crustal rocks and the garnet overgrowths Ib.

In stage IIa, the increase in Ca concentration, together with the decrease in $\delta^{18} \mathrm{O}$, indicates the onset of a chemically open system. A silicic magma, produced through partial melting of the local crust, and a mafic magma from the mantle may have interacted to produce a hybrid magma from which the resident garnet crystals developed their third growth zone (IIa). The presence of abundant apatite inclusions in this zone is consistent with this interpretation. During partial melting, tiny crystals of accessory minerals (such as Fe-Ti oxides, zircon and apatite), which are typically included within biotite crystals, are released as the mica breaks down to produce the melt. The melt phase is likely to be localised initially where former biotite crystals were concentrated. Such a reaction-related localisation of melt has been 
previously identified in high-grade metapelitic rocks that passed through the amphibolite- to granulite-facies transition in the middle crust (e.g. Powell and Downes 1990). In this situation, large garnet porphyroblasts grew within the localised leucosomes. The accessory crystals, now entrained into the migrating melt, may become included in the first new layers of garnet that are precipitated, thus producing the type of inclusion-rich zone that we observe as IIa. In addition, peraluminous melts are capable of dissolving substantial concentrations of P (e.g. Watson and Capobianco 1981; Watson et al. 1983; Bea et al. 1992). It is also possible to form disequilibrium melts that can be undersaturated in accessory-mineral components and yet contain residual crystals of those accessory minerals (e.g. Sawyer 1991; Srogi et al. 1993; Barbero et al. 1995; Bea 1996; Janák et al. 2001; Clemens 2003; Villaros et al 2009; McLeod et al. 2012). Post-Archaean mafic magmas contain an average of $0.32 \mathrm{wt} \% \mathrm{P}_{2} \mathrm{O}_{5}$, which is rather higher than in granitic magmas, which contain an average of $0.11 \mathrm{wt} \%$ (GERM database - https://earthref.org/GERMRD/130/). Since apatite solubility decreases with increasing $\mathrm{SiO}_{2}$ content (e.g. Watson 1979), mixing of mantle and crustal components, to form a hybrid magma from which the IIa-garnet was formed, would result in oversaturation in $\mathrm{P}$ and, once again, apatite precipitation. Thus, as garnet began to precipitate in stage IIa, films of melt, supersaturated in incompatible $\mathrm{P}$ would have been created around the garnet crystals. This, in turn, would have resulted in precipitation of new apatite crystals attached to the garnet rims, and these would then have been overgrown as garnet precipitation continued.

Lower $\delta^{18} \mathrm{O}$ values in zone IIa probably reflect variations in the isotopic composition of the hybrid melt from which garnet crystallised. Following Vielzeuf et al. (2005), we assume that the $\delta^{18} \mathrm{O}$ of this melt was controlled by the compositions of the minerals from which the original melts formed and the extent of mixing between the end members. With negligible fractionation of $\mathrm{O}$ isotopes between melt and garnet at magmatic temperatures, and taking values of $\delta^{18} \mathrm{O} \approx 14 \%$ for the crustal melt (Taylor and Sheppard 1986) and 5.7\% for the 
mantle melt (Kyser 1986), garnet zones with $\delta^{18} \mathrm{O}$ as low as $7.3 \%$ must have grown in a hybrid melt with the mantle component forming the dominant fraction (Vielzeuf et al 2005). The fourth zone, with relatively low $\delta^{18} \mathrm{O}$ values and consistently low $\mathrm{P}$ contents, is ascribed to crystallization of garnet during retrograde cooling. This would be an unlikely interpretation in a closed system at equilibrium, where garnet that formed during partial melting should ideally dissolve or react out during solidification. However, such garnet retrogression may not occur in cases of melt loss from the system (White and Powell, 2002). In an open-system in which the bulk composition changes with time, through ingress and/or expulsion of melt fractions, this lack of retrograde reaction is responsible for both the preservation of garnet in migmatites and the high proportion of garnet in leucosomes (e.g. Nicoli et al., 2017).

Here, we will focus on the contrasting behaviours of divalent cations as well as $\mathrm{P}$ or Ti, in terms of growth and diffusion zoning, and how this impacts the use of Ca diffusion profiles for determination of the durations of magma interactions in the crust. With zircon $\mathrm{U}-\mathrm{Pb}$ dating, we will also establish the date of the thermal event and determine whether zircon crystals, and their growth zones, record the same history as the garnet crystals. Finally, we will determine what $\mathrm{Hf}$ isotope ratios in zircon reveal about the nature of the magmas that interacted during this Hercynian thermal event.

\section{Further developments on the growth history of garnet crystals Contrasting behaviour of $\mathrm{Ca}, \mathrm{P}$ and $\mathrm{Ti}$ and the importance of $\mathrm{P}$ in garnet}

The EMP images discussed above highlight the different behaviours of $\mathrm{P}$ and $\mathrm{Ca}$ in garnet. Here we seek to explain the origin of this difference. Since the effective ionic radii of $\mathrm{Si}^{4+}(40$ pm) and $\mathrm{P}^{5+}$ (31 and $43 \mathrm{pm}$, for four-fold and five-fold coordination, respectively (Shannon 1976)) are similar, the substitution of silicon by phosphorus in tetrahedral sites is expected and has been experimentally observed in garnet (Koritnig 1965; Konzett and Frost 2009; 
Brunet et al 2006). If tetravalent $\mathrm{Si}$ is replaced by pentavalent $\mathrm{P}$, a charge balance is necessary, and a coupled substitution of some sort must be involved. At high pressure, a substitution involving sodium [e.g. $(\mathrm{Ca}, \mathrm{Fe}, \mathrm{Mg})^{2+}+\mathrm{Si}^{4+}=\mathrm{Na}^{+}+\mathrm{P}^{5+}($ Thompson 1975)] is consistent with experimental data (Brunet et al. 2006), as well as natural garnet crystals that contain high concentrations of both $\mathrm{P}$ and $\mathrm{Na}$. However, this substitution favoured by higher pressure may not occur at low pressure in garnet crystals that are almost Na-free. High concentrations of $\mathrm{P}$ have been observed in nearly Na-free pegmatitic garnet crystals, and the following substitution mechanism has been proposed: $\mathrm{M}^{2+}+2 \mathrm{Si}^{4+}=\square+2 \mathrm{P}^{5+}$ (Breiter et al. 2005). In the present case, the garnet maps in Fig. 6 indicate a positive correlation between $P$ and $\mathrm{Ti}$, and a negative correlation between these two elements and $\mathrm{Al}$. Thus, a mechanism such as ${ }^{\mathrm{IV}} \mathrm{P}^{5+}+{ }^{\mathrm{VI}} \mathrm{Ti}^{4+}+{ }^{\mathrm{VIII}} \square={ }^{\mathrm{IV}} \mathrm{Si}^{4+}+{ }^{\mathrm{VI}} \mathrm{Al}^{3+}+{ }^{\mathrm{VIII}} \mathrm{M}^{2+}$ (with $\mathrm{M}=\mathrm{Ca}, \mathrm{Mg}$ or Fe) could be involved. As a word of caution, the determination of substitution mechanisms is difficult to accomplish with certainty when elements with low concentrations (e.g. P and Ti) and others with high concentrations (e.g. $\mathrm{Al}$ and $\mathrm{Si}$ ) are involved. Nevertheless, the suggested substitution mechanism is the most consistent with our observations.

Concerning the replacement of Si by $\mathrm{P}$ in the $\mathrm{Z}$ site, it should be recalled that garnet crystals are nesosilicates, which means that $\mathrm{Si}$ atoms occupy $\mathrm{Z}$ sites in isolated $\left[\mathrm{SiO}_{4}\right]^{4-}$ tetrahedra. There, the relatively short $\mathrm{Si}-\mathrm{O}$ bonds $(1.635 \AA$ in pyrope or $1.645 \AA$ in grossular) are similar to the $\mathrm{P}-\mathrm{O}$ bond lengths in phosphorous pentoxide $\mathrm{P}_{2} \mathrm{O}_{5}$ (one short double-bond of $1.43 \AA$ and three long single bonds of $1.60 \AA$ ). Thus, in garnet crystals, four-fold coordination of $\mathrm{P}$ on the $\mathrm{Z}$ sites is likely to occur. Indeed, based on structures of silicate and phosphate minerals and melts, Ryerson and Hess (1980) noted that phosphate and silicate anions have similar structures, in which both $\mathrm{Si}^{4+}$ and $\mathrm{P}^{5+}$ are tetrahedrally coordinated with $\mathrm{O}$. The situation for $\mathrm{Ti}$ is more uncertain. Some studies suggest that $\mathrm{Ti}^{4+}$ is incorporated primarily 
into the tetrahedral (Z) site (Armbruster and Geiger 1993), while others, based on intracrystalline variations (Auzanneau et al 2010; Proyer et al 2013; Ackerson et al 2017) and XANES analyses (Waychunas 1987), suggest that Ti is accommodated in octahedral Y sites; we favour this second option.

Silicon is the slowest diffusing species in various silicate minerals, including garnet; see Shimojuku et al. (2014) for a review. This is due to the fact that the $\mathrm{SiO}_{4}$ groups are very stable and that little disorder is expected on the $\mathrm{Z}$ sites, including the presence of vacancies, which are of primary interest for diffusion. Following the same argument, P should also diffuse slowly. For entropic reasons, heterogeneous concentrations of $\mathrm{P}$ atoms (substituting for $\mathrm{Si}$ ) will tend to homogenize at high temperatures. However, the isolated character of the $\left[\mathrm{PO}_{4}\right.$ or $\left.\mathrm{SiO}_{4}\right]$ tetrahedra prevents a direct jump from one $\mathrm{Z}$ site to another. The obligation for $\mathrm{Si}$ or $\mathrm{P}$ to proceed through intermediate stages in unfavourable $\mathrm{X}$ or $\mathrm{Y}$ sites must retard diffusion of these atoms. On the other hand, Ca atoms prefer multiply coordinated environments, and $\mathrm{Ca}^{2+}$, together with $\mathrm{Fe}^{2+}, \mathrm{Mg}^{2+}$ or $\mathrm{Mn}^{2+}$, occupies the dodecahedral $\mathrm{X}$ sites with 8 oxygens in their corners. Thus, a high degree of disorder is expected in $\mathrm{X}$ sites. Diffusion of these atoms is facilitated by this disorder and also for topological reasons, since each dodecahedron shares edges with four neighbouring dodecahedra, which facilitates jumps between adjacent $\mathrm{X}$ sites.

If the sharpness of the chemical patterns observed in the EMP maps (e.g. Ca and P in Fig. 4) is taken as a qualitative indication of the relative diffusivities of the elements, the following hierarchy of diffusivities can be established $D(\mathrm{P})<D(\mathrm{Ti}), D(\mathrm{Al}), D(\mathrm{Cr})<D(\mathrm{Ca}), D(\mathrm{Y})<$ $D(\mathrm{Mg}), D(\mathrm{Fe}), D(\mathrm{Mn})$. However, if differences between $\mathrm{P}$ and Ti on one hand and divalent cations on the other hand are well established, the other rankings will need to be constrained through additional observations. In agreement with this ordering, Vielzeuf et al. (2005) noted that $\mathrm{P}$ or Ti could be viewed as the most stable markers of growth zoning in garnet, against 
which diffusion profiles of other components could be evaluated. This conclusion was experimentally demonstrated for Ti in the seed-overgrowth interdiffusion (SOI) experiments carried out by Vielzeuf et al. $(2007,2011)$. In these experiments, while smooth relaxation profiles were observed for $\mathrm{Ca}, \mathrm{Fe}$ and $\mathrm{Mg}$, sharp Ti transitions were observed between the garnet seeds and their overgrowths (see Fig. 1 of Vielzeuf et al. 2011). Using the $\mathrm{Ca}-(\mathrm{Fe}, \mathrm{Mg})$ interdiffusion coefficient that will be discussed in the next section, and comparing $\mathrm{Ca}$ and $\mathrm{P}$ profiles in the natural garnet crystals from Fig. 5, the diffusivity of $\mathrm{P}$ in garnet is constrained to be at least two orders of magnitude lower than that of $\mathrm{Ca}$, at temperatures around $860{ }^{\circ} \mathrm{C}$. Concerning $\mathrm{Ti}$, and using a similar approach, the experimental profiles of $\mathrm{Ca}$ and $\mathrm{Ti}$ determined by Vielzeuf et al (2007) at $1100{ }^{\circ} \mathrm{C}$ and $1.3 \mathrm{GPa}$ indicate that the diffusivity of $\mathrm{Ti}$ in garnet is lower by at least an order of magnitude than the diffusivity of $\mathrm{Ca}$ at that temperature. These estimates are upper limits, and the diffusivities of $\mathrm{P}$ and $\mathrm{Ti}$ in garnet could be lower.

\section{Diffusion profiles and time constraints}

The relaxation of chemical heterogeneities associated with growth zoning in garnet can be used to determine the durations of geological events, and this represents a useful complement to radiometric dating (Chakraborty and Ganguly 1992; Vielzeuf et al. 2007); see Ganguly (2010) for an extensive review. One of the major problems when dealing with diffusion of divalent cations in garnet is the large uncertainties in the determinations of diffusion coefficients, especially for $\mathrm{Ca}$. Indeed, at temperatures around $850{ }^{\circ} \mathrm{C}$, the largest and smallest diffusion coefficients determined for $\mathrm{Ca}$ in garnet differ by five orders of magnitude (Fig. 8 of Vielzeuf et al. 2007; and also Ganguly 2010, Li et al. 2018), which translates to a similar range of timescales. 

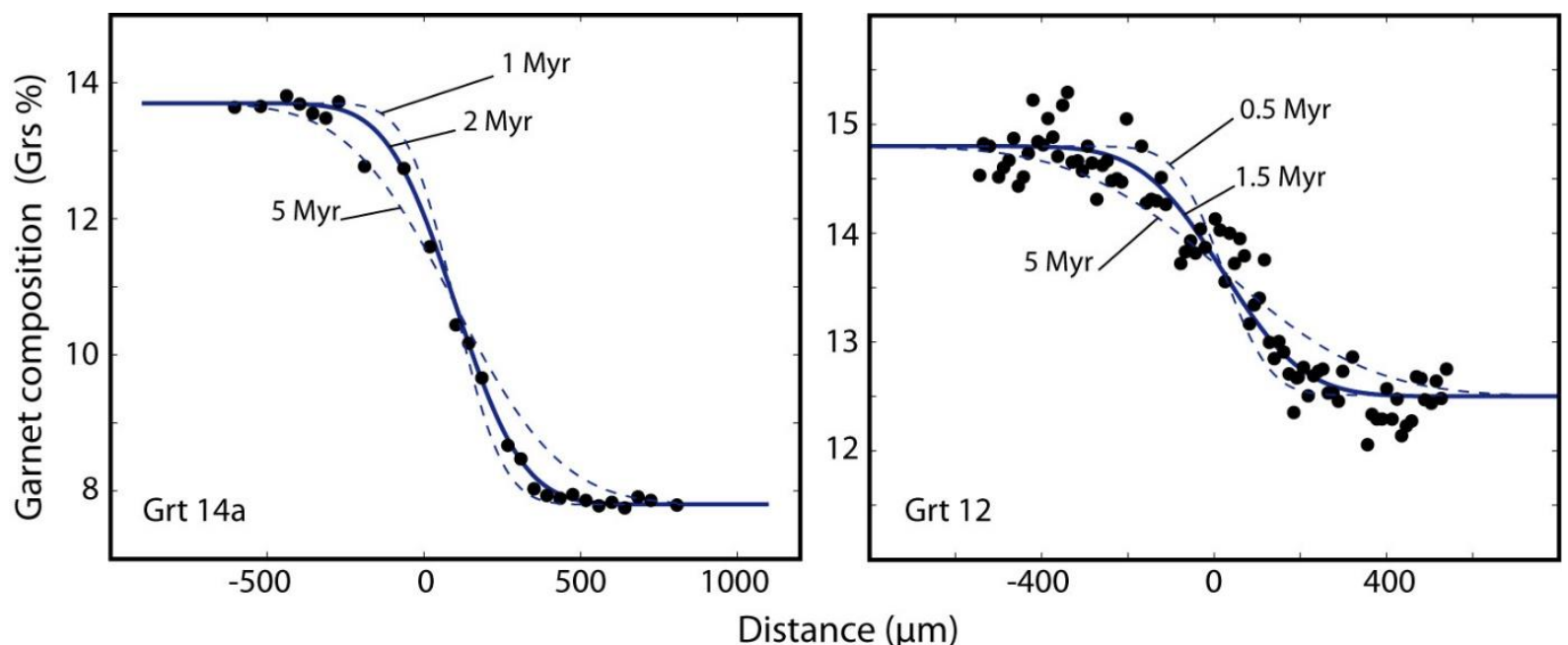

Fig. 7. Grossular profiles in two garnet crystals (Grt12 - Fig. 1 in Vielzeuf et al. (2005) - Grt14a-Fig. 5a) and diffusion penetration curves calculated for different durations, with the $\mathrm{Ca}-(\mathrm{Fe}, \mathrm{Mg})$ interdiffusion coefficient of Vielzeuf et al. (2007)

To lessen the uncertainties, Vielzeuf et al. $(2007,2011)$ carried out experiments to determine the diffusivities of $\mathrm{Ca}$ in garnet. To retrieve diffusion coefficients from experimental penetration curves, these authors used two approaches. First, the data were treated in terms of a binary $\mathrm{Ca}-(\mathrm{Fe}, \mathrm{Mg})$ interdiffusion coefficient, independent of composition (Vielzeuf et al. 2007). Each diffusion profile was modelled according to the solution of the diffusion equation in two semi-infinite media with a common interface and contrasting compositions (Crank 1975). In most cases, this simple approach and the temperature dependence of the $\mathrm{Ca}-(\mathrm{Fe}, \mathrm{Mg})$ diffusion coefficient is considered sufficient to process natural Ca diffusion profiles in garnet, and retrieve timescales of events. Second, the experimental data were processed using a multicomponent diffusion formalism (Vielzeuf and Saúl 2011). The four elements of the diffusion matrix relevant to the specific compositions and physical conditions of experimental profiles were retrieved by inversion methods. The two offdiagonal coefficients were determined directly, without dependence on any theoretical model for the origins of the multicomponent interactions. The thermal dependencies of all the coefficients of the $D$ matrix were determined and extrapolated to lower temperatures, which allows their use to determine the timescales of events from $\mathrm{Ca}, \mathrm{Fe}, \mathrm{Mg}$ garnet zoning profiles. 
Due to its low concentration in the studied garnets, Mn was not taken into consideration in the latter processing of the experimental data. On the basis of this experimental study, and for the present natural case, the following $D$ matrix was calculated at $860^{\circ} \mathrm{C}$ and $0.6 \mathrm{GPa}: \mathrm{DFeFe}=$ $1.78 \cdot 10^{-23}, \mathrm{DFeMg}=-4.62 \cdot 10^{-23}, \mathrm{DMgFe}_{\mathrm{Mge}}=-5.88 \cdot 10-^{24}, \mathrm{DMgMg}=6.83 \cdot 10^{-22}($ with $\mathrm{Ca}$ as the dependent component and Mn ignored).

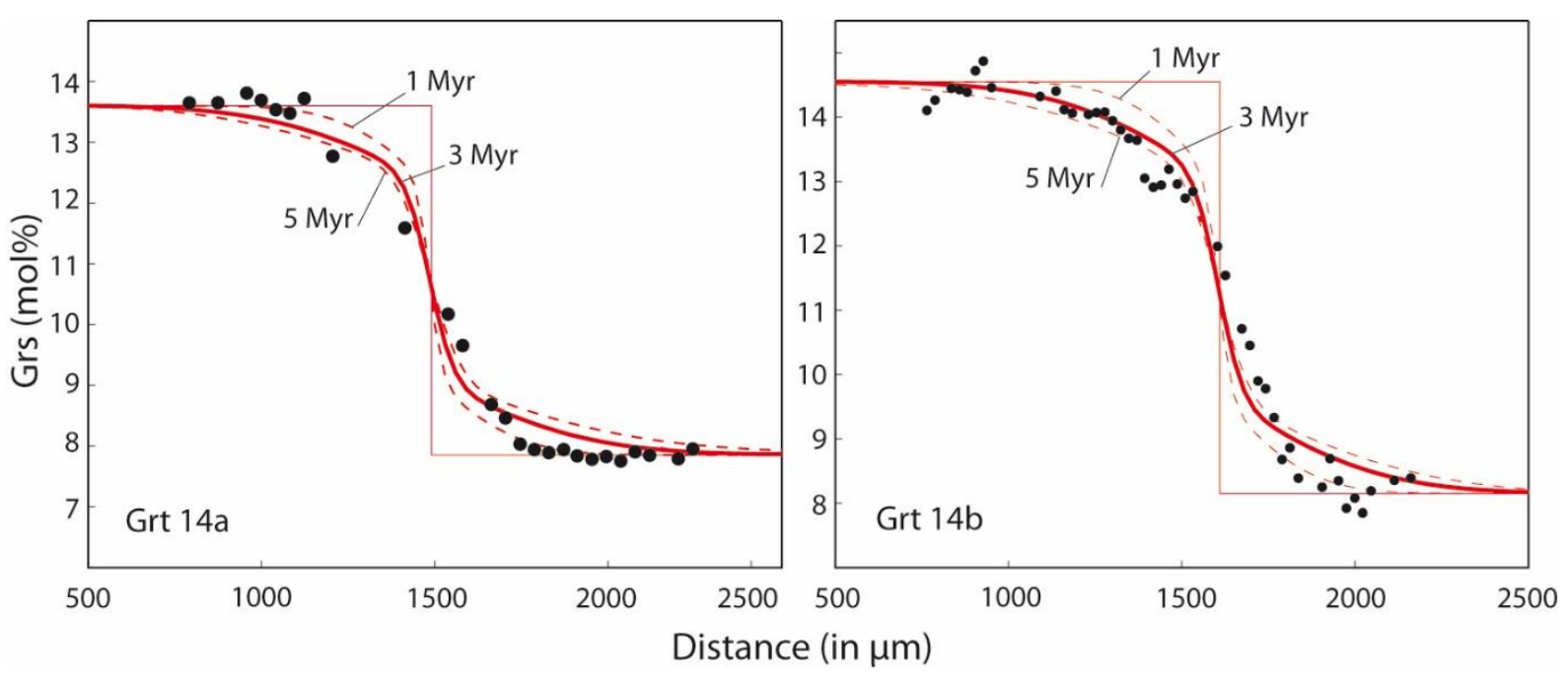

Fig. 8. Grossular profiles in garnet crystals Grt14a and b-Fig 5a and b. Diffusion profiles calculated with the coefficients of the D matrix determined by Vielzeuf and Saúl (2017)

As stated above, in diffusion modelling, the selection of diffusion coefficients among available datasets is a critical aspects. The main justification for preferring the data of Vielzeuf et al. $(2007,2011)$ is the fact that the experimental data encompass a larger temperature range than in any other experimental study, and do not require large downtemperature extrapolations for applications to the rocks under investigation. In addition, the Ca diffusion coefficients determined in these studies are valid for grossular concentrations in the range 3.4 to $20 \mathrm{~mol} \%$ Grs. The compositions that we are dealing with in the Ursuya rocks ( 7.5 to $15 \mathrm{~mol} \%$ Grs) are similar to those of the diffusion couple in the experiments of Vielzeuf et al. (2007, 2011). 
Figure 7 shows two grossular profiles fitted using the $\mathrm{Ca}-(\mathrm{Fe}, \mathrm{Mg})$ interdiffusion method discussed above (method 1) at a constant $T$ and $P$ of $860{ }^{\circ} \mathrm{C}$ and $0.6 \mathrm{GPa}$. The two adjustments indicate a duration of between 1 and $5 \mathrm{Myr}$, with a best estimate of 1.5 to $2 \mathrm{Myr}$, to generate the observed diffusion patterns $\left(D_{[\mathrm{Ca}-(\mathrm{Fe}+\mathrm{Mg})]}=2.31 \cdot 10^{-22}\right)$. Unlike temperature, pressure variations have no significant effect on these estimates. Calculations for temperatures of 810 and $910^{\circ} \mathrm{C}$ (corresponding to an error bar of $\pm 50{ }^{\circ} \mathrm{C}$ ) give the following results for the Grt14a case: $D_{[\mathrm{Ca}-(\mathrm{Fe}+\mathrm{Mg})]}=9.39 \cdot 10^{-23}$ and $5.26 \cdot 10^{-22} ; t=4.5$ and $0.8 \mathrm{Myr}$, at 810 and $910{ }^{\circ} \mathrm{C}$, respectively. It should be noted that the Ca diffusivities determined by Vielzeuf et al. (2011) converge within a narrow zone with those determined by Ganguly et al. (1998) at the temperature at which the modelling was carried out (intersection of the two regression lines at $750{ }^{\circ} \mathrm{C}$ in the Arrhenius plot (Fig. 8 in Vielzeuf et al. 2007). Thus, if the Ca diffusion coefficient of Ganguly et al $(1998)$ is used $\left(D_{[\mathrm{Ca}-(\mathrm{Fe}+\mathrm{Mg})]}=5.63 \cdot 10^{-22}\right)$ the duration estimate does not differ appreciably at $860{ }^{\circ} \mathrm{C}(t=0.8 \mathrm{Myr})$.

Figure 8 shows two sets of Ca chemical profiles, from garnet crystals 14a and 14b, fitted with the coefficients of the $D$ matrix indicated previously (multi-component diffusion). Penetration curves were calculated for durations of 1, 3 and 5 Myr. The Ca profile of the garnet is asymmetric; on the RHS, the data are fit better with the 1 Myr curve than with the 5 Myr curve. The converse is observed on the LHS of the profiles. We ascribe this feature to a compositional dependence of the coefficients of the $D$ matrix, which was ignored in these calculations. However, this effect is small and does not markedly affect the timescale determinations. In agreement with estimates obtained with method 1, averaging the optimal durations determined on each side of the profiles suggests that the time required to generate the $\mathrm{Mg}$ and Ca profiles is close to $2 \mathrm{Myr}$. The significance of these timescales will be discussed later, in combination with the zircon dating. 


\section{Information from the zircon crystals}

\section{In-situ U-Pb dating}

All the analysed zircon crystals are euhedral to subhedral, with slightly rounded edges. They are generally 150 to $200 \mu \mathrm{m}$ long, with short prismatic shapes and, apart from a few more elongate crystals, they have length/width ratios about 2 to 3 . The analytical results are reported in Supplementary Table S2 and Fig.10.

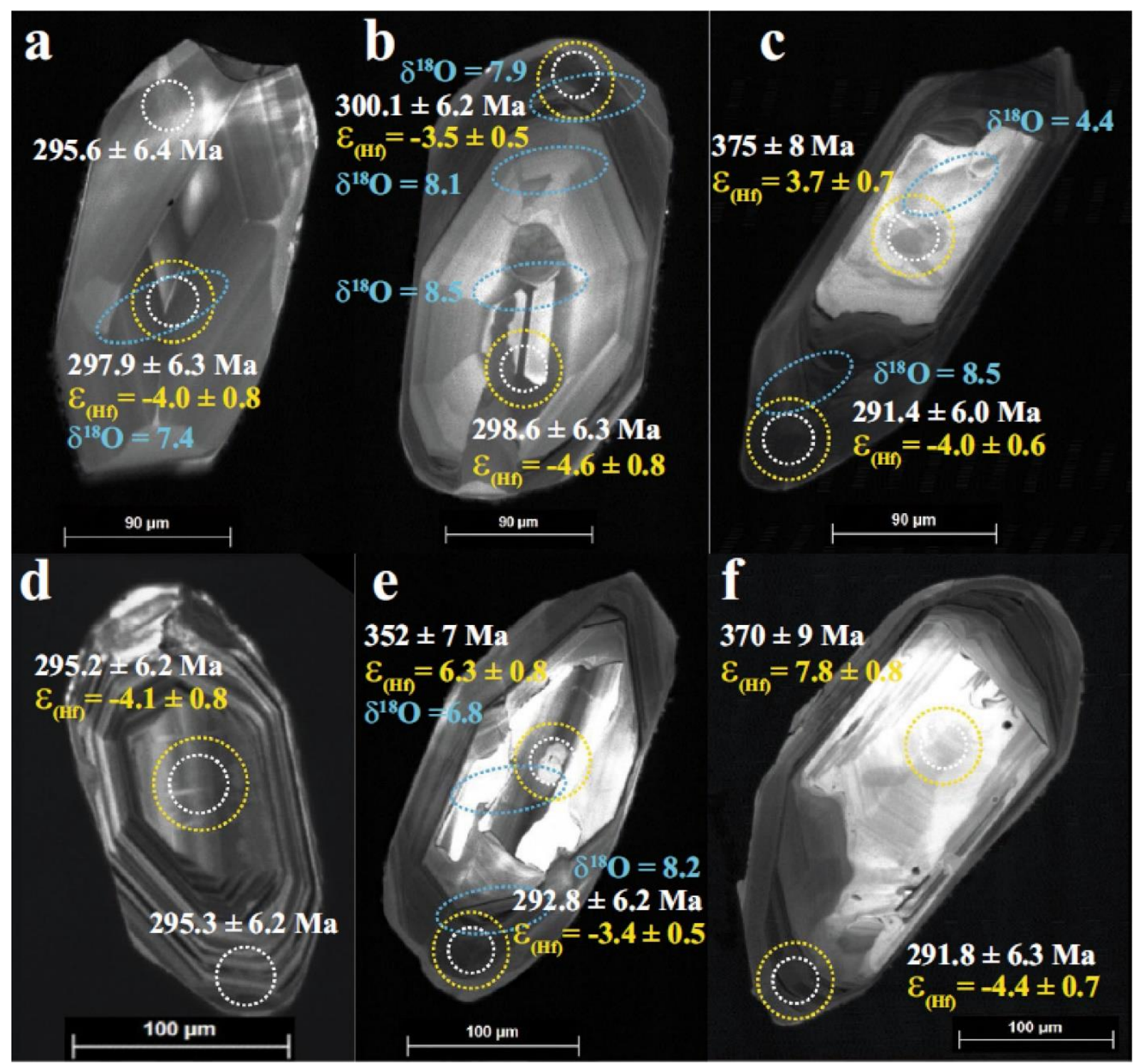

Fig. 9. Cathodoluminescence images of representative zircon crystals. Laser spots and corresponding U-Pb Concordia ages (in red) and $\varepsilon_{H f}\left(\right.$ in yellow) together with $\delta^{18} O$ (in blue) isotopic signatures are reported. a: euhedral grain from a norite globule, $\boldsymbol{b}$ : homogeneous crystal from the leucosome, $\boldsymbol{c}$ : composite zircon from the leucosome, $d$ : homogeneous grain from the melanosome, e and $f$ : composite crystals from the melanosome 


\section{Norite}

Zircon crystals recovered from the norite globules are characterised by oscillatory or sector zoning in the cathodoluminescence (CL) images (Fig. 9a). Their $\mathrm{U}$ and Th contents range from 40 to $300 \mathrm{ppm}(\overline{\mathrm{X}}=$ mean at $140 \pm 60 \mathrm{ppm} 1 \sigma)$ and from 10 to $200 \mathrm{ppm}(\overline{\mathrm{X}}=$ mean at 70 $\pm 50 \mathrm{ppm} 1 \sigma$ ), respectively. $\mathrm{Pb}$ contents are generally $<10 \mathrm{ppm}$ and $\mathrm{Th} / \mathrm{U}$ ratios display typical igneous values of $\sim 0.5 \pm 0.2$. A total of 51 spot analyses were carried out, 43 yielding a concordia age of $297.8 \pm 2.6 \mathrm{Ma}$ (Fig. 10a). This date is interpreted as the crystallization age of the zircon crystals during the emplacement of the noritic magma.

\section{Leucosome}

Two types of zircon are present in the leucosome. The first variety includes grains with homogeneous oscillatory or sector zoning in CL (Fig 9b). Their $\mathrm{U}$ and $\mathrm{Pb}$ contents vary from 110 to $900 \mathrm{ppm}$ and from 4 to $40 \mathrm{ppm}$, respectively, whereas their mean Th content is $70 \pm 40$ ppm. Their igneous-type mean $\mathrm{Th} / \mathrm{U}$ ratio is $\sim 0.3 \pm 0.2$. The 12 analyses corresponding to this group yield a concordia age of $297.6 \pm 3.3 \mathrm{Ma}$ (Fig. 10b), which is similar to that obtained from the zircon crystals of the norite sample. Thus, we conclude that these zircon crystals, at least those with the lowest U contents, were released through disaggregation of the norite, and became included within the migmatite during the partial melting event.

The second, and more abundant, variety consists of composite zircon crystals that generally contain light-coloured cores in CL, surrounded by dark, oscillatory zoned and Urich rims (Fig. 9c). Mean $\mathrm{U}$, Th and $\mathrm{Pb}$ concentrations of these rims are $440 \pm 120 \mathrm{ppm}, 16 \pm$ $8 \mathrm{ppm}$ and $19 \pm 5 \mathrm{ppm}$, respectively. Th/U ratios of these dark rims display typical "metamorphic" values of $0.04 \pm 0.03$. A total of 48 spot analyses were carried out on these 
rims, and yield a concordia age of 295.2 $\pm 2.4 \mathrm{Ma}$ (Fig. 10c). This age, in conjunction with the very low $\mathrm{Th} / \mathrm{U}$ ratios, is best interpreted as dating the crystallisation of newly formed rims during the partial melting event.

The light-coloured cores commonly contain oscillatory-zoned sections. Their U-Th- $\mathrm{Pb}$ concentrations are highly variable, and they always have igneous $\mathrm{Th} / \mathrm{U}$ ratios. Surprisingly, the age range is systematically Variscan (300 to $380 \mathrm{Ma}$ ), with a single grain at $440 \mathrm{Ma}$ and no Precambrian record (Fig. 10b).

\section{Melanosome}

As in the leucosome sample, the two same types of zircon are present. The minor population of oscillatory-zoned homogeneous crystals (Fig. 9d) displays U, Th and Pb contents of $270 \pm$ 170 ppm, $60 \pm 40$ ppm and 5 to 25 ppm, respectively. Pooled together, these zircon grains yield a lower intercept age of $297.6 \pm 5.0 \mathrm{Ma}$ (Fig. 10d), which is similar to that for the zircon crystals from both the norite and the equivalent homogeneous population in the leucosome. As in the case of the leucosome, this population is interpreted as inherited from disaggregated parts of the norite magma. As for the leucosome sample, the largest proportion of zircon crystals are composite grains with light-coloured cores in CL (Fig. 9e and f), characterized by high (igneous) Th/U ratios. Most of these cores yield Variscan ages of 300 to $480 \mathrm{Ma}$, but a few have concordant to sub-concordant Neoproterozoic and Neoarchaean ages of about 1.0 and $2.6 \mathrm{Ga}$ (Fig. 10d and e). These cores are also surrounded by zoned rims that are darker in CL (Fig. 9e and f), with U, Th and Pb contents of $380 \pm 130$ ppm, $14 \pm 7$ ppm and $16 \pm 6$ ppm, respectively, as well as low "metamorphic" values of Th/U $(0.04 \pm 0.02)$. Out of the 44 spots analysed in these rims, 36 define a concordia age of $294.8 \pm 2.4 \mathrm{Ma}$ (Fig. 10f), similar to zircon crystal ages from the leucosome sample. This age is interpreted as the time of 
crystallization from a contaminated partial melt, after the norite pluton was emplaced into the surrounding metasedimentary rocks.
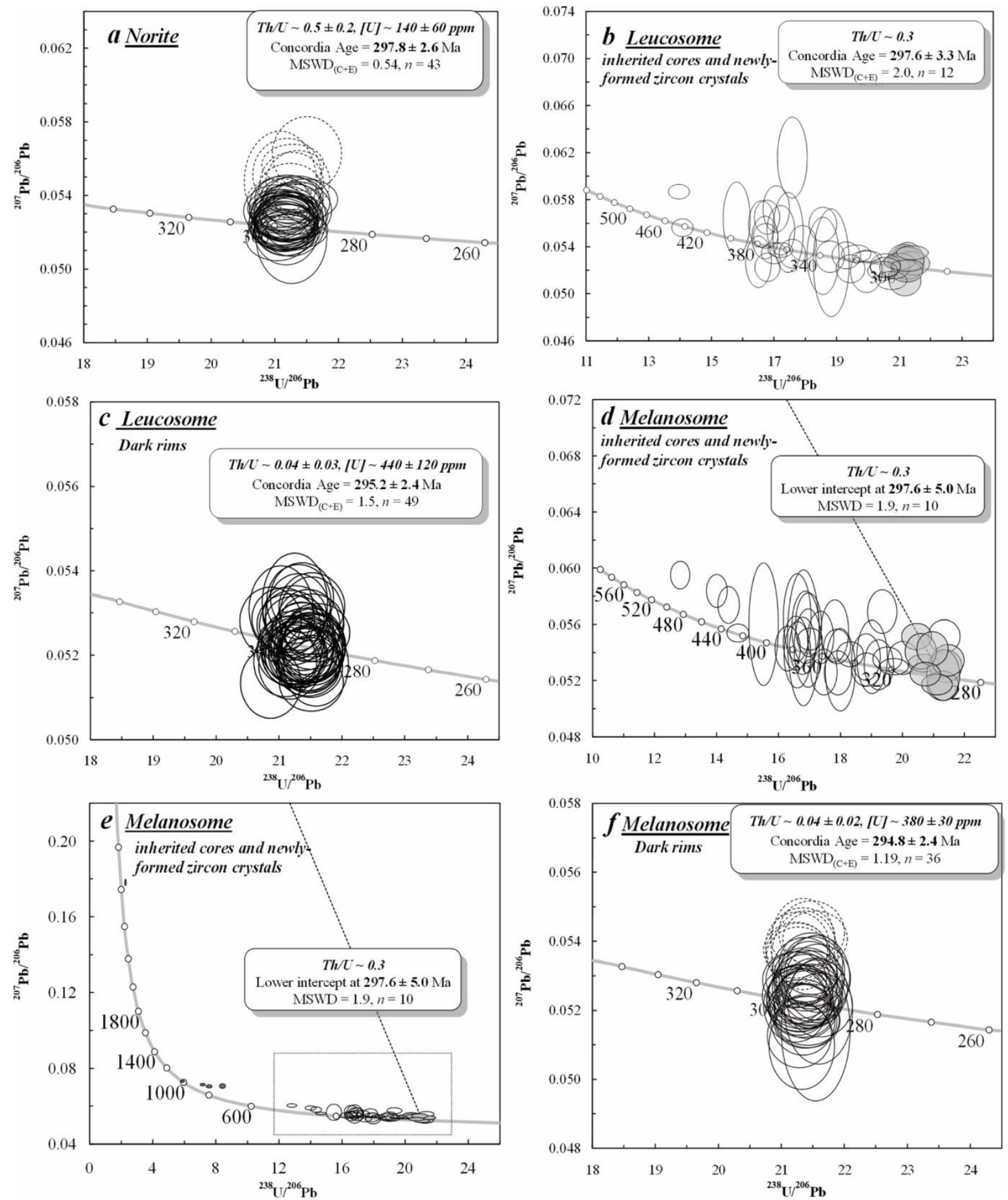

Fig. 10. ${ }^{238} U{ }^{206} \mathrm{~Pb}$ versus ${ }^{207} \mathrm{~Pb} /{ }^{06} \mathrm{~Pb}$ Tera and Wasserburg (1972) diagrams of the studied samples; $\boldsymbol{a}$ : zircon crystals from the norite globules, $\boldsymbol{b}$ : inherited cores and newly-formed zircon crystals from the leucosome, $\boldsymbol{c}$ : $C L$-dark rims of the zircon crystals from the leucosome, $\boldsymbol{d}$ (zoom) and $\boldsymbol{e}$ : inherited cores and newly-formed zircon crystals from the melanosome, $f$ : CL-dark rims of the zircon crystals from the melanosome 


\section{In-situ $\delta^{18} \mathrm{O}$ ratios}

Seven homogeneous zircon grains from the norite were analysed by SIMS. Their $\delta^{18} \mathrm{O}$ values range from 7.3 to $8 \%$, with a mean of $7.7 \pm 0.2 \%$. An homogeneous zircon from the leucosome yielded a value of 8.2\% (Fig. 9b). Most commonly in the leucosome, zircon crystals are composite; the cores have a mean value of $5.8 \pm 1.2 \%$ o $(n=8, \min .=4.4 \%$, $\max$. $=7.8 \%$, Fig. 9c $)$ while the rims have higher $\delta^{18} \mathrm{O}(\mathrm{n}=8$, mean $=8.5 \pm 0.3 \%$ o $)$. A similar pattern is observed in the melanosome [cores: $\mathrm{n}=4$, $\min .=5.4 \%$, $\max .=7.6 \%$, mean $=6.4$ $\pm 1 \%$ with rims: $\mathrm{n}=5$, min. $=8.1 \%$, max. $=9 \%$, mean $=8.5 \pm 0.4 \%$, Fig. $9 \mathrm{e}]$. To summarize, the rims of the zoned zircon crystals in leucosomes and melanosomes have $\delta^{18} \mathrm{O}$ values similar to those of the zircon crystals from the norite $(\sim 8 \%)$, indistinguishable from those measured in the Ca-rich garnet rims. The zircon cores of the leucosome and melanosome have lower $\delta^{18} \mathrm{O}$ values $(\sim 6 \%)$.

\section{In-situ Hf isotope analyses}

Zircon grains from the norite yield sub-chondritic initial $\varepsilon \mathrm{Hf}(\mathrm{t})$ values ranging from -2 to -5 (Supplementary Table S3 and Fig.11). In agreement with the 1.0 to $1.1 \mathrm{Ga}$ Hf model ages, these values imply that the source rock consisted mostly of depleted-mantle materials mixed with sufficient amounts of recycled, most likely older, continental crust enriched in radiogenic Hf. Thus, the zircon crystals from the norite are not directly derived from a depleted mantle reservoir, which implies a complex series of metamorphic and magmatic events. We suggest that previous interactions of mantle-derived mafic magma, with moderate assimilation of crustal material, probably of sedimentary origin, within the mantle or the deep crust, may be responsible for the Hf signature of the norite. In this case, the Hf-depleted mantle signature 
would have been masked by the assimilation of metasediment-derived older crustal zircon grains.

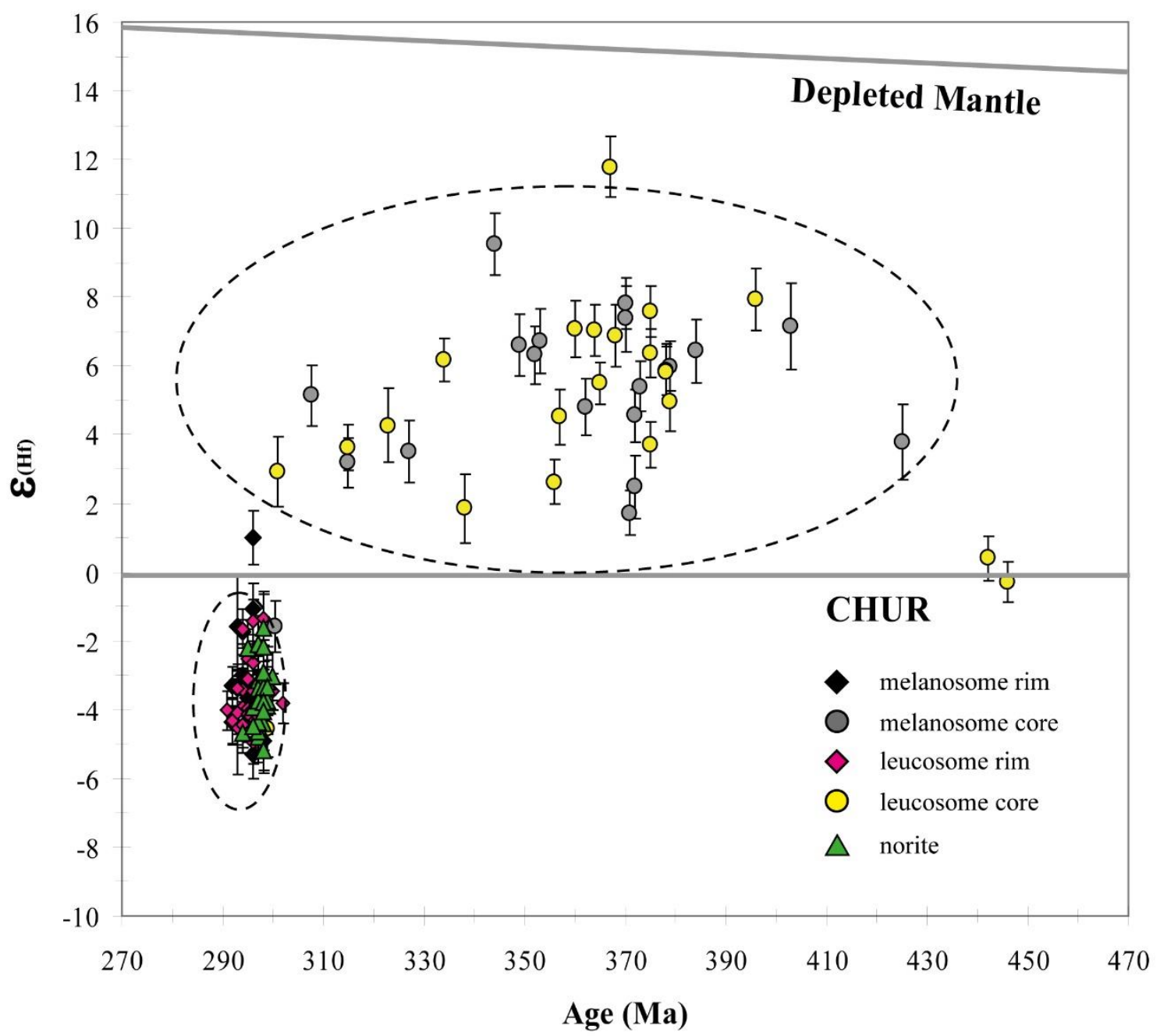

Fig. 11. Diagram showing $\mathcal{E}_{H f}$ versus time for the studied zircon crystals.

The composite zircon crystals from both leucosomes and melanosomes have cores with Variscan ages and supra-chondritic initial $\varepsilon \mathrm{Hf}(\mathrm{t})$ values ranging from 0 to +12 . Thus, these zircon cores are interpreted as derived from protoliths that were extracted from a depletedmantle magmatic source. Since these initial $\varepsilon_{\mathrm{Hf}}(\mathrm{t})$ values are lower than those of rocks derived from the Depleted Mantle (DM), such as mid-ocean-ridge basalts, the DM here was probably 'contaminated' by some recycled continental crust and/or significantly metasomatised. Both 
hypotheses are compatible with the 0.5 to $0.9 \mathrm{Ga}$ Hf model ages. Surprisingly, the zircon cores from the whole migmatite (leucosome plus melanosome) yield Hf signatures closer to typical depleted mantle values than zircon crystals from the norite globules. Since the crustal source was metasedimentary, these sediments must have been formed by weathering and erosion of igneous materials that were emplaced in some appropriate tectonic environment during this long 440 to 300 Ma time period.

In the composite zircon crystals from the leucosome and melanosome, the dark rims have the same initial $\varepsilon \mathrm{Hf}(\mathrm{t})$ values as the zircon crystals from the norite (-1 to -6$)$. Thus, the source of the composite zircon crystals drastically changed over time, with crystallisation of cores from $440 \mathrm{Ma}$, in a juvenile environment, to the formation of rims in the recycled continental crust at $295 \mathrm{Ma}$. Owing to these distinct $\mathrm{Hf}$ isotope signatures, the rims cannot have been derived from the same source as the cores, and the source of the rims from the composite zircon crystals cannot be distinguished from that of the zircon crystals in the norite.

Finally, the small proportion of homogeneous zircon crystals, dated at $298 \mathrm{Ma}$ and sampled in both migmatitic facies, have $\varepsilon \mathrm{Hf}(\mathrm{t})$ values that are compatible with the range of values recorded in the zircon crystals from the norite. Thus, Hf isotopes confirm the hypothesis that the migmatitic samples contain zircon crystals from disaggregated fragments of the norite magma.

\section{Discussion}

\section{Summary of the observations and interpretation}

Before discussing our results further, we present a summary of the main findings and interim conclusions:

- In these rocks, garnet crystals are most commonly zoned, with a Ca-rich and P-poor rims. 
- The $\delta^{18} \mathrm{O}$ values are higher in the garnet cores $(11.6-14.4 \%)$ than in the garnet rims $(11.6-7.3 \%)$.

- The transitions from core to rim are sharp for slow-diffusing species such as $\mathrm{P}$ and $\mathrm{Ti}$, and progressive for $\mathrm{Ca}, \mathrm{Fe}, \mathrm{Mg}$ and $\mathrm{Y}$.

- Modelling of the Ca diffusion profiles implies a duration of $2 \pm 1$ Myr for the thermal event that was responsible for the chemical exchanges.

- Two types of zircon crystals are observed in the leucosomes and melanosomes: homogeneous and composite zircon crystals. Homogeneous zircon crystals are similar to those observed in the norite. Composite zircon crystals have old, inherited core with mantle geochemical signatures. Zircon rims have characteristics close to those of the norite.

- Zircon crystals from the norite are homogeneous, with lower $\mathrm{U}$ and $\mathrm{Pb}$, and higher $\mathrm{Th}$ contents and $\mathrm{Th} / \mathrm{U}$ ratios, but similar $\delta^{18} \mathrm{O}$ ratios to the zircon rims from the leucosomes and melanosomes. See Table 1 for a summary of the results.

- The $\varepsilon \mathrm{Hf}(\mathrm{t})$ of the norite zircon crystals and the zircon rims from the leucosomes and melanosomes are similar (-6 to -1$)$ and point to crystallization from crustally contaminated mantle melts.

- The Concordia ages of the norite zircon crystals (298 Ma) and the leucosome and melanosome zircon rims (295 Ma) are similar (within analytical uncertainties).

\section{Implications for the late-Hercynian thermal event in the Pyrenees}

Apart from some rare 1 to $3 \mathrm{Ga}$ ages, most zircon cores in the leucosomes yield ages of about $370 \pm 20 \mathrm{Ma}$. In these zircon crystals, the Hf signatures are close to those of typical depleted mantle. These zircon crystals could be the signatures of magmas that formed and were emplaced during early Hercynian events. They could be related to the first genetic group of I- 
type magmatism reported by Finger et al. (1997) and interpreted as volcanic-arc granites related to the subduction of early Variscan oceans. The fact that such zircon crystals are found in granulitic metasedimentary rocks indicates that early igneous crystals went through a cycle of weathering, erosion, sedimentation and metamorphism prior to being subjected to effects of the noritic intrusion, at $298 \mathrm{Ma}$. These observations imply that materials extracted from the mantle can undergo a complete cycle during a single orogeny, and that $70 \mathrm{Myr}$ (from about 370 to $300 \mathrm{Ma}$ ) is sufficient to encompass the entire set of processes and events. This conclusion is consistent with the idea that fertile sedimentary materials were involved in the Hercynian orogenic cycle, and this explains the abundance of granitic rocks that formed during the late heating stage of the Hercynian cycle (Pin and Vielzeuf 1983; Vielzeuf et al 1990).

In these migmatitic diorites, both garnet and zircon zoning features are consistent with the idea that metasedimentary rocks were affected by thermal and chemical interactions with a noritic magma. The mineralogical and major-element characters of the norite indicate an origin from a mantle-derived magma. However, the chemical signature of the norite zircon crystals indicates their crystallization from a magma that was hybridised by sufficient crustal material to produce a crustal Hf isotopic signature. Thus, we envision a multi-stage spatial and temporal process, with mantle-crust exchanges possibly taking place in a lower-crustal magma reservoir (a deep-crustal hot zone? - Annen et al. 2006), followed by emplacement of the contaminated magma into the middle crust, where an additional stage of chemical exchange took place. Zircon and garnet crystals from the studied rocks recorded this second stage. The presence of norite globules, of various sizes, scattered through the dioritic migmatite, indicates that both mechanical and chemical exchanges took place. With such processes, that involve different spatial scales (from the $\mu \mathrm{m}$ for chemical diffusion to 
decametre for mechanical mixing), a broad range of behaviour can be expected, producing poorly mingled to efficiently mixed materials.

Concerning the duration of the thermal event that was registered by the zoning in the zircon and garnet crystals, it was shown earlier that the norite zircon crystals may be slightly older than the leucosome and melanosome zircon rims. This age difference, of about $3 \mathrm{Myr}$, is interpreted as the maximum time required to transform the previously metamorphosed rocks (garnet being already present) by heating, partial melting, chemical exchange and mechanical mingling, in response to the intrusion of noritic magmas. The age of the noritic zircon crystals would thus correspond to the beginning of the process, while the age of the leucosome and melanosome zircon rims would represent the final phase. We acknowledge that the measured dates are within analytical uncertainties. Thus, this difference provides an upper limit of the duration. The timescale for the interactions between noritic, mantle-derived and crustal melts could be shorter, but not longer, since a greater age difference would be registered by the zircon crystals. This is a situation in which coupling zircon dating and diffusion studies of minerals becomes necessary. As Ca diffusion profiles in garnet indicate an interval of $2 \pm 1$ Myr for the combined thermal and chemical events, these numbers are most likely in the correct order of magnitude for the duration of this type of geological event.

As discussed in the introduction, if we accept the idea of a genetic relationship between granulites and granitic rocks, we would expect the granites to be at least slightly younger than the granulite-facies metamorphism that formed them. However, as indicated in Fig. 1, most granitic plutons in the Pyrenees are older than 300 Ma. This surprising situation can be explained if the overall duration of the thermal event and the buffering effect of partial melting in a fertile crust are taken into account. Indeed, in response to a widespread thermal anomaly, the temperature in the lower crust is expected to increase until partial melting, the formation of granitic melts, and a first granulite-facies metamorphic event is underway. At 
this stage, and following the reasoning developed by Vielzeuf et al. (1990), heat consumed by the melting reactions may temporarily buffer the temperature until upward ascent of granitic magmas and their emplacement in the middle to upper crust has occurred. If the mantle thermal anomaly persists, the temperature in the lower crust may then increase further and generate a subsequent granulite event, which could be of younger age than the granites formed during this overall thermal cycle. Note that this conceptual model of dynamic crustal response to a mantle thermal anomaly is analogous to the concepts developed by Vielzeuf et al. (1990) for successive thermal events affecting a region of crust in successive orogenies. Here, we simply apply a similar concept to a single, overall thermal event with a succession in time and space of local thermal pulses. Clearly, this scenario, involving conductive heat transfer can be complicated locally by thermal pulses associated with advection of more or less hybridised mantle-derived magmas into the crust, as would be indicated by the presence of numerous mafic intrusions at different levels in the crust.

In the Pyrenees, the overall duration of the thermal event (or anomaly) that characterizes the late evolution of the Hercynian belt can be estimated as around 30 to $40 \mathrm{Myr}$ (Vielzeuf 1996); the oldest granites are dated at $317 \mathrm{Ma}$, while the Permian magmatism may mark the end of the cycle (at ca $280 \mathrm{Ma}$ ). This duration is consistent with the sedimentary gap observed in the Pyrenees, asynchronous from west to east but covering an overall period of 30 to 40 Myr (Vielzeuf and Autran, p. 570 in Vielzeuf 1996).

In this general context, the Ursuya rocks provide a snapshot of processes that occur when mafic magmas interact with partially molten rocks during a thermal pulse. Such 'frozen' situations, in which garnet crystals preserve textural evidence of disequilibria associated with mafic magmas, are rare in metamorphic settings. In this case, a possible explanation is that the event recorded in the Ursuya rocks occurred late, during the closing stage of the Hercynian thermal cycle, and that it was followed by rapid cooling, possibly associated with extension 
driven by movements along major shear zones (Vissers 1992). This hypothesis also provides an explanation for the contrasting durations determined for magmatic interactions in the Ursuya rocks (ca $2 \mathrm{Myr}$ ) and the overall duration of the thermal anomaly, at the scale of the Pyrenean chain (ca 30 to $40 \mathrm{Myr}$ ). In the studied cases above, divalent cations in garnet crystals diffused over distances of about $1 \mathrm{~mm}$ in 2 to $3 \mathrm{Myr}$. Diffusion distances would be around ten times longer for durations of 30 to $40 \mathrm{Myr}$. This means that garnet heterogeneities, due to crustal-mantle melt interactions that happened early during the Hercynian thermal cycle, may no longer be detectable. This is another reason why these types of interactions are difficult to observe in the field.

\section{Conclusions}

Pin and Vielzeuf (1983) provided the first general interpretation of the occurrence of granulite-facies rocks in the Hercynian belt. They noted a duality of granulitic events: an early high- $P$ event related to compressive stages during crustal subduction, and a late low- to medium- $P$ granulitic event that annealed the deepest parts of the Variscan belt. Pin and Vielzeuf (1983) anticipated similar dualities in other collisional belts. To our present knowledge, such a duality has not been confirmed elsewhere, but it is unknown whether this is due to an erroneous prediction or the rarity of the particular combination of events necessary for both the formation and surface exposure of such rocks (e.g. by superposition of a subsequent major orogenic event, such as the Alpine orogeny). The dioritic migmatites from the Ursuya massif in the Pyrenees and the garnet and zircon crystals within them represent a window into the fine structure of protracted thermal events during an orogeny that might involve a complex series of events. Indeed, such studies represent efficient means of detecting such complex thermomechanical histories. From the work of Etheridge et al. (2021), we know how highly efficient partial melting and magma withdrawal can be. This means that crustally 
derived granitic magmas ascend rapidly to higher levels. It is commonly held that granites represent signals of crustal growth and differentiation. Combining studies of minerals that preserve parts of the history of a crustal differentiation event, with the bigger picture provided by the granitic rocks, represents a way of understanding how heat pulses arrived, and possibly of estimating their intensities and causes. Once there are several such studies from different areas, it should be possible to identify any systematics concerning the timings of thermal events, or contrasts in timings in different tectonic settings.

\section{Acknowledgements}

The help with the SIMS and EMP analyses by C. Rollion-Bard and M. Veschambre are gratefully acknowledged by DV. GS funded a 3-week stay for DV at the University of Stellenbosh through National Research Foundation funding provided via a SARChI grant.

\section{References}

Ackerson MR, Watson EB, Tailby ND, Spear FS (2017) Experimental investigation into the substitution mechanisms and solubility of Ti in garnet. Am Mineral 102(1-2):158-172, https://doi.org/10.2138/am-2017-5632

Annen C, Blundy JD, Sparks RSJ (2006) The Genesis of Intermediate and Silicic Magmas in Deep Crustal Hot Zones. J Petrol 47: 505-539, https://doi.org/10.1093/petrology/egi084 Armbruster T, Geiger CA (1993) Andradite crystal-chemistry, dynamic X-site disorder and structural strain in silicate garnets. European J Mineral 5(1):59-71

Auzanneau E, Schmidt MW, Vielzeuf D, Connolly JAD (2010) Titanium in phengite: a geobarometer for high temperature eclogites. Contrib Mineral Petrol 159(1):1-24, https://doi.org/10.1007/s00410-009-0412-7 
Barbero L, Villaseca C, Rogers G, Brown PE (1995) Geochemical and isotopic disequilibrium In crustal melting - an insight from the anatectic granitoids from Toledo, Spain. J Geophys Res 100: 15745-15765, https://doi.org/10.1029/95JB00036

Bea F (1996) Controls on the trace element composition of crustal melts. Trans R Soc Edinburgh Earth Sci 87: 33-41, https://doi.org/10.1017/S0263593300006453

Bea F, Fershtater G, Corretge LG (1992) The geochemistry of phosphorus in granite rocks and the effect of aluminum. Lithos 29: 43-56, https://doi.org/10.1016/00244937(92)90033-U

Boissonnas J (1974) Iholdy, carte géologique détaillée au 1/50000 ${ }^{\mathrm{ème}}$. Service géologique national - Bureau de Recherches Géologiques et Minières, Orléans, France

Breiter K, Novak M, Koller F, Cempirek J (2005) Phosphorus - an omnipresent minor element in garnet of diverse textural types from leucocratic granitic rocks. Mineral Petrol 85(3-4): 205-221, https://doi.org/10.1007/s00710-005-0086-4

Brunet F, Bonneau V, Irifune T (2006) Complete solid-solution between $\mathrm{Na}_{3} \mathrm{Al}_{2}\left(\mathrm{PO}_{4}\right)_{3}$ and $\mathrm{Mg}_{3} \mathrm{Al}_{2}\left(\mathrm{SiO}_{4}\right)_{3}$ garnets at high pressure. Am Mineral 91(1):211-215, https://doi.org/10.2138/am.2006.2053

Chakraborty S, Ganguly J (1992) Cation diffusion in aluminosilicate garnets - Experimental determination in spessartine-almandine diffusion couples, evaluation of effective binary diffusion-coefficients, and applications. Contrib Mineral Petrol 111(1):74-86, https://doi.org/10.1007/bf00296579

Chappell BW, White AJR (1974) Two contrasting granite types. Pacific Geol 8: 173-174 Chappell BW, White AJR (2001) Two contrasting granite types: 25 years later. Aust J Earth Sci 48: 489-499, https://doi.org/10.1046/j.1440-0952.2001.00882.x

Chu NC, Taylor RN, Chavagnac V, Nesbitt RW, Boella RM, Milton JA, German CR, Bayon G, Burton K (2002) Hf isotope ratio analysis using multi-collector inductively coupled 
plasma mass spectrometry: an evaluation of isobaric interference corrections. J Anal Atomic Spectrom 17: 1567-1574, https://doi.org/10.1039/B206707B

Clarke DB, Rottura A (1994) Garnet-forming and garnet-eliminating reactions in a quartz diorite intrusion at Capo-Vaticano, Calabria, Southern Italy. Canadian Mineral 32: 623-635

Clemens JD (1990) The granulite - granite connexion. In: Vielzeuf D, Vidal P (eds)

Granulites and Crustal Differentiation, Kluwer Academic Publishers, Dordrecht, pp 25-36

Clemens JD (2003) S-type granitic magmas-petrogenetic issues, models and evidence. Earth-Sci Rev 61: 1-18, 10.1016/s0012-8252(02)00107-1

Clemens JD, Bezuidenhout A (2014) Origins of co-existing diverse magmas in a felsic intrusion: the Lysterfield Granodiorite, Australia. Contrib Mineral Petrol 167: 197-212, https://doi.org/10.1007/s00410-014-0991-9

Clemens JD, Elburg MA, Harris C (2017) Origins of microgranular igneous enclaves in granitic rocks: the example of Central Victoria, Australia. Contrib Mineral Petrol 172: 88, https://doi.org/10.1007/s00410-017-1409-2

Clemens JD, Stevens G, Farina F (2011) The enigmatic sources of I-type granites and the clinopyroxene-ilmenite connexion. Lithos 126: 174-181, https://doi.org/10.1016/j.lithos.2011.07.004

Connolly JAD (2009) The geodynamic equation of state: What and how. Geochem Geophys Geosys 10, https://doi.org/10.1029/2009gc002540

Conrad WK, Nicholls IA, Wall VJ (1988) Water-saturated and -undersaturated melting of metaluminous and peraluminous crustal compositions at $10 \mathrm{~kb}$ : evidence for the origin of silicic magmas in the Taupo Volcanic Zone, New Zealand, and other occurrences. J Petrol 29: 765-803, https://doi.org/10.1093/petrology/29.4.765

Etheridge MA, Daczko NR, Chapman T, Stuart CA (2021) Mechanisms of melt extraction during lower crustal partial melting. J Metamorphic Geol, 39(1), 57-75, 
https://doi.org/10.1111/jmg.12561

Finger F, Roberts MP, Haunschmid B, Schermaier A, Steyrer HP (1997) Variscan granitoids of central Europe: their typology, potential sources and tectonothermal relations. Mineral Petrol 61(1-4): 67-96, https://doi.org/10.1007/bf01172478

Fisher CM, Hanchar JM, Samson SD, Dhuime B, Blichert-Toft J, Vervoort J, Lam R (2011b) Synthetic zircon doped with hafnium and rare earth elements: a reference material for in situ hafnium isotope analysis. Chem Geol 286: 32-47

Fisher CM, McFarlane CRM, Hanchar JH, Schmitz MD, Sylvester PJ, Lam R, Longerich HP (2011a) Sm-Nd isotope systematics by laser ablation-multicollector-inductively coupled plasma mass spectrometry: methods and potential natural and synthetic reference materials. Chem Geol 284: 1-20.

Ganguly J, Singh RN, Ramana DV (1995) Thermal perturbation during charnockitization and granulite-facies metamorphism in Southern India. J Metamorphic Geol 13(3): 419-430, https://doi.org/10.1111/j.1525-1314.1995.tb00229.x

Ganguly J (2010) Cation Diffusion Kinetics in Aluminosilicate Garnets and Geological Applications. In: Zhang YX, Cherniak DJ (eds) Diffusion in Minerals and Melts, vol 72. pp 559-601

Green TH (1976) Experimental generation of cordierite-bearing or garnet-bearing granitic liquids from a pelitic composition. Geology 4(2): 85-88, https://doi.org/10.1130/00917613(1976)4<85:egocgg $>2.0 . c 0 ; 2$

Hiess J, Condon DJ, McLean N, Noble SR, (2012) ${ }^{238} \mathrm{U} /{ }^{235} \mathrm{U}$ systematics in terrestrial uranium-bearing minerals. Science 335: 1610-1614

Holland T, Powell R (2003) Activity-composition relations for phases in petrological calculations: an asymmetric multicomponent formulation. Contrib Mineral Petrol 145(4): 492-501, https://doi.org/10.1007/s00410-003-0464-z 
Holland TJB, Powell R (2011) An improved and extended internally consistent thermodynamic dataset for phases of petrological interest, involving a new equation of state for solids. J Metamorphic Geol 29(3): 333-383, https://doi.org/10.1111/j.15251314.2010.00923.x

Horstwood MSA, Košler J, Gehrels G, Jackson S., McLean N, Paton C., Pearson NJ, Sircombe K, Sylvester P, Vermeesch P, Bowring JF, Condon DJ, Schoene B, (2016) Community-derived standards for LA-ICP-MS U-(Th-)Pb geochronology - Uncertainty propagation, Age interpretation and data reporting. Geostand Geoanal Res 40(3) 311-332

Hurai V, Paquette JL, Huraiová M, Konečný P (2010) Age of deep crustal magmatic chambers in the intra-Carpathian back-arc basin inferred from LA-ICPMS U-Th-Pb dating of zircon and monazite from igneous xenoliths in alkali basalts. J Volcanol Geotherm Res 198: $275-287$

Iizuka T, Yamaguchi T, Hibiya Y, Amelin Y (2015) Meteorite zircon constraints on the bulk $\mathrm{Lu}-\mathrm{Hf}$ isotope composition and early differentiation of the Earth. Proc Nat Acad Sci 112: $5331-5336$

Jackson SE, Pearson NJ, Griffin WL, Belousova E.A (2004) The application of laser ablationinductively coupled plasma-mass spectrometry to in situ U-Pb zircon geochronology. Chem Geol 211: 47-69

Janák M, Petrík I, Poller U (2001) Disequilibrium melting in Early Devonian (406 Ma) orthogneisses from the Western Tatra Mts. Geolines 13: 66-67

Konzett J, Frost DJ (2009) The High P-T Stability of Hydroxyl-apatite in Natural and Simplified MORB-an Experimental Study to $15 \mathrm{GPa}$ with Implications for Transport and Storage of Phosphorus and Halogens in Subduction Zones. J Petrol 50(11): 2043-2062, https://doi.org/10.1093/petrology/egp068

Kyser TK (1986) Stable isotope variations in the mantle. Rev Mineral 16:141-164 
Li BW, Ge JH, Zhang BH (2018) Diffusion in garnet: a review. Acta Geochim 37(1): 19-31, https://doi.org/10.1007/s11631-017-0187-x

Ludwig KR (2001) User's manual for Isoplot/Ex Version 2.49, a geochronological toolkit for Microsoft Excel. Berkeley Geochronological Center, Special Publication 1a, Berkeley, USA, $55 \mathrm{pp}$

Lupulescu A, Watson EB (1999) Low melt fraction connectivity of granitic and tonalitic melts in a mafic crustal rock at $800^{\circ} \mathrm{C}$ and $1 \mathrm{GPa}$. Contrib Mineral Petrol 134: 202-216, https://doi.org/10.1007/s004100050479

Mayne MJ, Moyen JF, Stevens G, Kaislaniemi L (2016) Rcrust: a tool for calculating pathdependent open system processes and application to melt loss. J Metamorphic Geoly 34(7): 663-682, https://doi.org/10.1111/jmg.12199

McBirney AR (1980) Mixing and unmixing of magmas. J Volc Geotherm Res 7: 357-371, https://doi.org/10.1016/0377-0273(80)90038-4

McLeod CL, Davidson JP, Nowell GM, de Silva SL (2012) Disequilibrium melting during crustal anatexis and implications for modelling open magmatic systems. Geology 40: 435438, https://doi.org/10.1130/G33000.1

Moyen JF, Paquette JL, Ionov DA, Gannoun A, Korsakov AV, Golovin AV, Moine B (2017) Paleoproterozoic rejuvenation and replacement of Archaean lithosphere: evidence from zircon $\mathrm{U}-\mathrm{Pb}$ dating and $\mathrm{Hf}$ isotopes in crustal xenoliths at Udachnaya, Siberian craton. Earth Planet Sci Lett 457: 149-159

Nicoli G, Stevens G, Moyen J-F, Vezinet A, Mayne M (2017) Insights into the complexity of crustal differentiation: $\mathrm{K}_{2} \mathrm{O}$-poor leucosomes within metasedimentary migmatites from the Southern Marginal Zone of the Limpopo Belt, South Africa. J Metamorphic Geol 35: 9991022. 
Paquette JL, Ionov DA, Agashev AM, Gannoun A, Nikolenko EI (2017) Age, provenance and Precambrian evolution of the Anabar Shield from U-Pb and Lu-Hf isotope data on detrital zircons, and the history of the northern and central Siberian craton. Precam Res 301: $134-144$

Paquette JL, Piro JL, Devidal JL, Bosse V, Didier A (2014) Sensitivity enhancement in LAICP-MS by $\mathrm{N}_{2}$ addition to carrier gas: application to radiometric dating of $\mathrm{U}$-Th-bearing minerals. Agilent ICP-MS J 58: 4-5

Patchett PJ, Kouvo O, Hedge CE, Tatsumoto M (1981) Evolution of continental crust and mantle heterogeneity: evidence from Hf isotopes. Contrib Mineral Petrol 78: 279-297

Patchett PJ, Tatsumoto M (1980) Hafnium isotope variations in oceanic basalts. Geophys Res Lett 7: 1077-1080

Patiño Douce AE, Johnston AD (1991) Phase-equilibria and melt productivity in the pelitic system - Implications for the origin of peraluminous granitoids and aluminous granulites. Contrib Mineral Petrol 107(2): 202-218

Pin C, Vielzeuf D (1983) Granulites and related rocks in Variscan median Europe - A dualistic interpretation. Tectonophysics 93(1-2): 47-74, https://doi.org/10.1016/00401951(83)90233-0

Powell R, Downes J (1990) Garnet porphyroblast-bearing leucosomes in metapelites: mechanisms, phase diagrams, and an example from Broken Hill, Australia. In: Ashworth JR, Brown M (eds) High-temperature Metamorphism and Crustal Anatexis, UnwinHyman, London, pp 105-123

Proyer A, Habler G, Abart R, Wirth R, Krenn K, Hoinkes G (2013) $\mathrm{TiO}_{2}$ exsolution from garnet by open-system precipitation: evidence from crystallographic and shape preferred orientation of rutile inclusions. Contributions to Mineralogy and Petrology 166(1): 211234, https://doi.org/10.1007/s00410-013-0872-7 
Rollion-Bard C, Blamart D, Cuif JP, Juillet-Leclerc A (2003) Microanalysis of C and O isotopes of azooxanthellate and zooxanthellate corals by ion microprobe. Coral Reefs 22(4): 405-415, https://doi.org/10.1007/s00338-003-0347-9

Ryerson FJ, Hess PC (1980) The role of $\mathrm{P}_{2} \mathrm{O}_{5}$ in silicate melts. Geochim Cosmochim Acta 44(4): 611-624, https://doi.org/10.1016/0016-7037(80)90253-7

Sawyer EW (1991) Disequilibrium melting and the rate of melt-residuum separation during migmatization of mafic rocks from the Grenville Front, Quebec. J Petrol 32: 701-738, https://doi.org/10.1093/petrology/32.4.671

Scherer E, Münker C, Mezger K (2001) Calibration of the lutetium-hafnium clock. Science 293: $683-687$

Shannon, R.D., 1976. Revised effective ionic-radii and systematic studies of interatomic distances in halides and chalcogenides. Acta Crystal Sect A 32: 751-767

Shimojuku A, Kubo T, Kato T, Yoshino T, Nishi M, Nakamura T, Okazaki R, Kakazu Y (2014) Effects of pressure and temperature on the silicon diffusivity of pyrope-rich garnet. Phys Earth Planet Int 226: 28-38, https://doi.org/10.1016/j.pepi.2013.11.002

Sparks RSJ, Marshall LA (1986) Thermal and mechanical constraints on mixing between mafic and silicic magmas. J Volc Geotherm Res 29: 99-124, https://doi.org/10.1016/03770273(86)90041-7

Spear FS, Kohn MJ (1996) Trace element zoning in garnet as a monitor of crustal melting. Geology 24(12): 1099-1102, https://doi.org/10.1130/00917613(1996)024<1099:teziga>2.3.co;2

Srogi L, Wagner ME, Lutz TM (1993) Dehydration partial melting and disequilibrium in the granulite-facies Wilmington Complex, Pennsylvania-Delaware Piedmont. Am J Sci 293: 405-462, https://doi.org/10.2475/ajs.293.5.405 
Stevens G, Clemens JD, Droop GTR (1997) Melt production during granulite-facies anatexis: experimental data from "primitive" metasedimentary protoliths. Contrib Mineral Petrol 128: 352-370, https://doi.org/10.1007/s004100050

Taylor HP, Sheppard SMF (1986) Igneous rocks. 1. Processes of isotopic fractionation and isotope systematics. Rev Mineral 16: 227-271

Tera F, Wasserburg GJ (1972) U-Th-Pb systematics in three Apollo 14 basalts and the problem of initial $\mathrm{Pb}$ in lunar rocks. Earth Planet Sci Lett 14: 281-304

Thompson AB, Connolly JAD (1995) Melting of the continental-crust - some thermal and petrological constraints on anatexis in continental collision zones and other tectonic settings. J Geophys Res 100: 15565-15579, https://doi.org/10.1029/95JB00191

Thompson RN (1975) Is upper-mantle phosphorus contained in sodic garnet? Earth and Planetary Science Letters 26(3): 417-424, https://doi.org/10.1016/0012-821x(75)90017-5 van Achterbergh E, Ryan CG, Jackson SE, Griffin W (2001) Data reduction software for LAICP-MS. In: Sylvester P (ed) Laser ablation-ICPMS in the Earth Sciences, vol 29, Mineralogical Association of Canada, pp 239-243

Vervoort D, Patchett PJ, Söderlund U, Baker M (2004) Isotopic composition of Yb and the determination of Lu concentrations and $\mathrm{Lu} / \mathrm{Hf}$ ratios by isotope dilution using MC-ICPMS. Geochem Geophys Geosys 5: 1-15

Vielzeuf D (1984) Relations de phases dans le faciès granulite et implications géodynamiques. L'exemple des granulites des Pyrénées. Thèse Etat. Université de Clermont-Ferrand (France) 287p, https://doi.org/10.13140/RG.2.2.34545.30561

Vielzeuf, D. (1996) Les massifs nord-pyrénéens à soubassement granulitique et la croûte hercynienne des Pyrénées : une synthèse, in Barnolas, A., and Chiron, J.C., eds., Synthèse Géologique et Géophysique des Pyrénées: edition BRGM - ITGE, 502-521 and 568-576. Vielzeuf D, Baronnet A, Perchuk AL, Laporte D, Baker MB (2007) Calcium diffusivity in 
alumino-silicate garnets: an experimental and ATEM study. Contrib Mineral Petrol 154(2): 153-170, https://doi.org/10.1007/s00410-007-0184-X

Vielzeuf D, Clemens JD, Pin C, Moinet E (1990) Granites, granulites and crustal differentiation. In: Vielzeuf D, Vidal P (eds) Granulites and Crustal Differentiation, Kluwer Academic Publishers, Dordrecht, pp 59-86

Vielzeuf D, Holloway JR (1988) Experimental determination of the fluid-absent melting reactions in the pelitic system. Consequences for crustal differentiation. Contrib Mineral Petrol 98: 257-276, https://doi.org/10.1007/BF00375178

Vielzeuf D, Montel J-M (1994) Partial melting of metagreywackes. Part I. Fluid-absent experiments and phase relationships. Contrib Mineral Petrol 117: 375-393, https://doi.org/10.1007/BF00307272

Vielzeuf D, Saúl A (2011) Uphill diffusion, zero-flux planes and transient chemical solitary waves in garnet. Contrib Mineral Petrol 161(5): 683-702, https://doi.org/10.1007/s00410010-0557-4

Vielzeuf D, Schmidt MW (2001) Melting relations in hydrous systems revisited: application to metapelites, metagreywackes and metabasalts. Contrib Mineral Petrol 141(3):2 51-267, https://doi.org/10.1007/s004100100237

Vielzeuf D, Veschambre M, Brunet F (2005) Oxygen isotope heterogeneities and diffusion profile in composite metamorphic-magmatic garnets from the Pyrenees. Am Mineral 90(23): 463-472, https://doi.org/10.2138/am.2005.1576

Villaros A, Buick IS, Stevens G (2012) Isotopic variations in S-type granites: an inheritance from a heterogeneous source? Contrib Mineral Petrol 163: 243-257, https://doi.org/10.1007/s00410-011-0673-9 
Villaros A, Stevens G, Moyen J-F, Buick IS (2009) The trace element compositions of S-type granites: evidence for disequilibrium melting and accessory phase entrainment in the source. Contrib Mineral Petrol 158: 543-561, https://doi.org/10.1007/s00410-009-0396-3

Watson EB (1979) Apatite saturation in basic to intermediate magmas. Geophys Res Lett 6: 937-940, https://doi.org/10.1029/GL006i012p00937

White RW, Powell R, Clarke GL (2002) The interpretation of reaction textures in Fe-rich metapelitic granulites of the Musgrave Block, central Australia: constraints from mineral equilibria calculations in the system $\mathrm{K} 2 \mathrm{O}-\mathrm{FeO}-\mathrm{MgO}-\mathrm{Al}_{2} \mathrm{O}_{3}-\mathrm{SiO}_{2}-\mathrm{H}_{2} \mathrm{O}-\mathrm{TiO}_{2}-\mathrm{Fe}_{2} \mathrm{O}_{3}$. J Metamorphic Geol 20(1): 41-55, https://doi.org/10.1046/j.0263-4929.2001.00349.x

White RW, Powell R, Holland TJB, Johnson TE, Green ECR (2014) New mineral activitycomposition relations for thermodynamic calculations in metapelitic systems. $\mathbf{J}$ Metamorphic Geol 32(3): 261-286, https://doi.org/10.1111/jmg.12071

White RW, Powell R, Holland TJB, Worley BA (2000) The effect of $\mathrm{TiO}_{2}$ and $\mathrm{Fe}_{2} \mathrm{O}_{3}$ on metapelitic assemblages at greenschist and amphibolite facies conditions: mineral equilibria calculations in the system $\mathrm{K}_{2} \mathrm{O}-\mathrm{FeO}-\mathrm{MgO}-\mathrm{Al}_{2} \mathrm{O}_{3}-\mathrm{SiO}_{2}-\mathrm{H}_{2} \mathrm{O}-\mathrm{TiO}_{2}-\mathrm{Fe}_{2} \mathrm{O}_{3}$. J Metamorphic Geol 18(5): 497-511, https://doi.org/10.1046/j.1525-1314.2000.00269.x

Watson EB, Capobianco CJ (1981) Phosphorus and the rare earth elements in felsic magmas: an assessment of the role of apatite. Geochim Cosmochim Acta 45: 2349-2358, https://doi.org/10.1016/0016-7037(81)90088-0

Waychunas GA (1987) Synchrotron radiation XANES spectroscopy of Ti in minerals Effects of Ti bonding distances, Ti valence, and site geometry on absorption-edge structure. Am Mineral 72(1-2): 89-101

White R W, Powell R (2002) Melt loss and the preservation of granulite facies mineral assemblages. J Metamorphic Geol 20(7): 621-632

Wiedenbeck M, Allé P, Corfu F, Griffin Wl, Meier M, Oberli F, Quadt AV, Roddick JC, 
Spiegel W (1995) Three natural zircon standards for U-Th-Pb, Lu-Hf, trace element and REE analyses. Geostandards Newslett 19: 1-23 